\title{
Seasonal and diel variations in the vertical distribution, composition, abundance and biomass of zooplankton in a deep Chilean Patagonian fjord
}

\author{
Nur Garcia-Herrera ${ }^{\text {Corresp., } 1,2}{ }^{\text {, Astrid Cornils }}{ }^{1}$, Jürgen Laudien ${ }^{1}$, Barbara Niehoff ${ }^{1}$, Juan Höfer ${ }^{3,4,5}$, Günter Försterra \\ ${ }^{3}$, Humberto E González ${ }^{4,6}$, Claudio Richter ${ }^{1,2}$ \\ ${ }^{1}$ Alfred Wegener Institute, Helmholtz Centre for Polar and Marine Research, Bremerhaven, Germany \\ 2 University of Bremen, Bremen, Germany \\ 3 Escuela de Ciencias del Mar, Pontificia Universidad Católica de Valparaíso, Valparaíso, Chile \\ 4 Research Center: Dynamics of High Latitude Marine Ecosystems (IDEAL), Punta Arenas, Chile \\ 5 Fundación San Ignacio de Huinay, Huinay, Chile \\ 6 Institute of Marine and Limnological Sciences, Universidad Austral, Valdivia, Chile \\ Corresponding Author: Nur Garcia-Herrera \\ Email address: nur.garcia.herrera@awi.de \\ Comau Fjord is a stratified Chilean Patagonian fjord characterized by a shallow brackish \\ surface layer and a > $400 \mathrm{~m}$ layer of aragonite-depleted subsurface waters. Despite the \\ energetic burden of low aragonite saturation levels to calcification, Comau Fjord harbours \\ dense populations of cold-water corals (CWC). While this paradox has been attributed to a \\ rich supply of zooplankton, supporting abundance and biomass data are so far lacking. In \\ this study, we investigated the seasonal and diel changes of the zooplankton community \\ over the entire water column. We used a Nansen net (100 $\mu \mathrm{m}$ mesh) to take stratified \\ vertical hauls between the surface and the bottom (0-50-100-200-300-400-450 m).
} Samples were scanned with a ZooScan, and abundance, biovolume and biomass were determined for 41 taxa identified on the web-based platform EcoTaxa 2.0. Zooplankton biomass was the highest in summer $\left(209 \mathrm{~g}\right.$ dry mass $\left.\mathrm{m}^{-2}\right)$ and the lowest in winter $(61 \mathrm{~g}$ dry mass $\mathrm{m}^{-2}$ ). Abundance, however, peaked in spring, suggesting a close correspondence between reproduction and phytoplankton spring blooms (Chl a max. $50.86 \mathrm{mg} \mathrm{m}^{-3}, 3 \mathrm{~m}$ depth). Overall, copepods were the most important group of the total zooplankton community, both in abundance (64-81\%) and biovolume (20-70\%) followed by mysids and chaetognaths (in terms of biovolume and biomass), and nauplii and Appendicularia (in terms of abundance). Throughout the year, diel changes in the vertical distribution of biomass were found with a daytime maximum in the 100-200 m depth layer and a nighttime maximum in surface waters $(0-50 \mathrm{~m})$, associated with the diel vertical migration of the calanoid copepod family Metridinidae. Diel differences in integrated zooplankton 
abundance, biovolume and biomass were probably due to a high zooplankton patchiness driven by biological processes (e.g., diel vertical migration or predation avoidance), and oceanographic processes (estuarine circulation, tidal mixing or water column stratification). Those factors are considered to be the main drivers of the zooplankton vertical distribution in Comau Fjord. 


\section{Seasonal and diel variations in the vertical}

2 distribution, composition, abundance and biomass of

3 zooplankton in a deep Chilean Patagonian fjord

4 Nur Garcia-Herrera ${ }^{1,2}$, Astrid Cornils ${ }^{1}$, Jürgen Laudien ${ }^{1}$, Barbara Niehoff ${ }^{1}$, Juan Höfer 3 ,4,5,

5 Günter Försterra ${ }^{3}$, Humberto E. González ${ }^{4,6}$, Claudio Richter ${ }^{1,2}$

$7{ }^{1}$ Alfred Wegener Institute, Helmholtz Centre for Polar and Marine Research, Bremerhaven,

8 Germany

$9 \quad 2$ University of Bremen, Germany

$10{ }^{3}$ Escuela de Ciencias del Mar, Pontificia Universidad Católica de Valparaíso, Valparaíso, Chile

$11{ }^{4}$ Research Center: Dynamics of High Latitude Marine Ecosystems (IDEAL), Punta Arenas,

12 Chile

$13{ }^{5}$ Fundación San Ignacio de Huinay, Chile

$14{ }^{6}$ Institute of Marine and Limnological Sciences, Universidad Austral, Valdivia, Chile

Corresponding author:

17 Nur Garcia-Herrera

18 Am Alten Hafen 26, Bremerhaven, 27568, Germany

19 Email address: nur.garcia.herrera@awi.de 


\section{Abstract}

Comau Fjord is a stratified Chilean Patagonian fjord characterized by a shallow brackish surface layer and a $>400 \mathrm{~m}$ layer of aragonite-depleted subsurface waters. Despite the energetic burden of low aragonite saturation levels to calcification, Comau Fjord harbors dense populations of cold-water corals (CWC). While this paradox has been attributed to a rich supply of zooplankton, supporting abundance and biomass data are so far lacking. In this study, we investigated the seasonal and diel changes of the zooplankton community over the entire water column. We used a Nansen net (100 $\mu \mathrm{m}$ mesh) to take stratified vertical hauls between the surface and the bottom (0-50-100-200-300-400-450 m). Samples were scanned with a ZooScan, and abundance, biovolume and biomass were determined for 41 taxa identified on the web-based platform EcoTaxa 2.0. Zooplankton biomass was the highest in summer $\left(209 \mathrm{~g}_{\text {dry }}\right.$ mass $\left.\mathrm{m}^{-2}\right)$ and the lowest in winter (61 g dry mass $\left.\mathrm{m}^{-2}\right)$. Abundance, however, peaked in spring, suggesting a close correspondence between reproduction and phytoplankton spring blooms (Chl $a$ max. $50.86 \mathrm{mg}$ $\mathrm{m}^{-3}, 3 \mathrm{~m}$ depth). Overall, copepods were the most important group of the total zooplankton community, both in abundance (64-81\%) and biovolume (20-70\%) followed by mysids and chaetognaths (in terms of biovolume and biomass), and nauplii and Appendicularia (in terms of abundance). Throughout the year, diel changes in the vertical distribution of biomass were found with a daytime maximum in the 100-200 $\mathrm{m}$ depth layer and a nighttime maximum in surface waters $(0-50 \mathrm{~m})$, associated with the diel vertical migration of the calanoid copepod family Metridinidae. Diel differences in integrated zooplankton abundance, biovolume and biomass were probably due to a high zooplankton patchiness driven by biological processes (e.g., diel vertical migration or predation avoidance), and oceanographic processes (estuarine circulation, tidal mixing or water column stratification). Those factors are considered to be the main drivers of the zooplankton vertical distribution in Comau Fjord.

Keywords. zooplankton, seasonality, diel vertical migration, cold-water corals (CWC), ZooScan, EcoTaxa, Comau Fjord, Chilean Patagonia.

\section{Introduction}

Coastal marine ecosystems are among the most productive on earth (Mann \& Lazier, 1991). They provide substantial economic and ecological services, such as high biological production, nutrient cycling or shoreline stability and erosion control (Escribano, Fernández \& Aranís, 2003; Liu et al., 2010; Pan et al., 2013; Barbier, 2017). The Chilean fjord region extends over large and complex hydrographic and geomorphologic conditions, particularly rich in productivity and 
biodiversity (Försterra, Häussermann \& Laudien, 2017; Häussermann, Försterra \& Laudien, 2021), but also endangered by human exploitation, which has been increasing significantly - e.g. salmon aquaculture - over the last two decades (Iriarte, González \& Nahuelhual, 2010; Buschmann, Niklitschek \& Pereda, 2021; Navedo \& Vargas-Chacoff, 2021).

The hydrography of the fjords and channels of Patagonia can be considered a transitional estuarine-marine system where a surface layer of silicate-rich terrestrial freshwater meets nitrateand phosphate-rich marine waters. These fjords receive freshwater from rivers, surface runoff and groundwater flow due to the high rainfall and glacier melting (Pantoja, Iriarte \& Daneri, 2011). The upper brackish layer within the top $10 \mathrm{~m}$ water depth is usually poor in nitrate and phosphate but rich in silicate and organic matter from terrestrial inputs (Sánchez, González \& Iriarte, 2011). Below the halocline, a water mass with higher salinity ( $>31)$, named Modified Subantarctic Water (MSAAW), flowing landward from the adjacent oceanic area provides the fjords with macronutrients (nitrate and phosphate). Both water masses, surface-freshwater and MSAAW, generate a two-layer structure in the water column with sharp vertical and more gradual horizontal salinity gradients (Sievers \& Silva, 2008; Pérez-Santos et al., 2014; Meerhoff et al., 2019). The summer stratification creates a barrier which may hinder the exchange of nutrients within the water column, altering the functioning of the pelagic food web and productivity patterns (Silva, Calvete \& Sievers, 1997; González et al., 2011). During austral spring, the Comau Fjord receives an intense riverine input of fresh water, rich in silicic acid used by bloom-generating diatoms and, thus, leading to high primary production (González et al., 2010). In austral summer, the high concentration of phytoplankton promotes an increase in the abundance and biomass of zooplankton as secondary producers (Antezana, 1999; González et al., 2010). In fjord systems, seasonal patterns are modulated by other oceanographic processes, such as estuarine circulation (Palma \& Silva, 2004), tidal regimes and lateral advection (Castro et al., 2011) or water column stratification (Sánchez, González \& Iriarte, 2011) influencing the zooplankton biomass and community structure on shorter time scales.

Zooplankton plays an essential role in the functioning of marine ecosystems and in the oceanic carbon cycle. It includes a wide variety of organisms and displays extreme variability in terms of community composition and vertical, seasonal and geographical distribution (Palma \& Kaiser, 1993). Many taxa are known to perform diel vertical migrations (DVM), most likely to evade predators (Stich \& Lampert, 1981; Iwasa, 1982). According to the predator-evasion hypothesis, migrating zooplankton resides in deep waters during daytime hours where the probability of being perceived by visually orientated predators is lower than if they remained in better illuminated shallow waters, and at night, in the refuge of darkness, they migrate upwards to feed. However, DVM is not performed by all organisms in a zooplankton community or even not by 
90

91

92

93

94

95

96

97

all individuals of one species. For example, while late copepodites and adults of the copepod genus Metridia migrate, a large fraction of the young developmental stages remains in surface waters, saving the energy of performing the DVM, suggesting a lower probability of being perceived and consumed by visual predators (Hays, 1995). Both, migrant and non-migrant species are important elements of the biological carbon pump via the production of sinking fecal pellets that transport carbon from surface waters to the seafloor (Urrère \& Knauer, 1981; Fowler \& Knauer, 1986; Emerson \& Roff, 1987). Zooplankton also provides a trophic link between primary production and higher consumers such as fish, birds and mammals, but also invertebrate predators, such as corals (Nemoto, 1970; Gili et al., 2006; Höfer et al., 2018).

Cold-water corals (CWC) rely on zooplankton as their principal food source to maintain their physiological processes, such as respiratory metabolism and growth (Carlier et al., 2009; Mayr et al., 2011; Naumann et al., 2011). Therefore, their diet depends on the zooplankton seasonal, diel and vertical distribution. In Comau Fjord, azooxanthellate scleractinian CWC are wide-spread even in deep aragonite-undersaturated waters (Häussermann \& Försterra, 2007; Fillinger \& Richter, 2013a; Jantzen et al., 2013a). In the latter, the dissolution of exposed parts of the skeleton, enhanced bioerosion, and reduced CWC growth and survival have been observed (McCulloch et al., 2012; Maier et al., 2016). The calcification of the CWC skeleton is energetically costly, and thus food requirements in these adverse environments are higher compared to aragonite-saturated waters (Maier et al., 2016). According to Fillinger \& Richter, (2013b), in Comau fjord, the CWC Desmophyllum dianthus thrives but coral densities decrease below $280 \mathrm{~m}$ despite available substrate, suggesting that lower oxygen and $\mathrm{pH}$ concentrations, combined with a shortage of zooplankton could be limiting coral growth. However, up to now little is known about the zooplankton of Comau Fjord in the northern Patagonian region and its role in sustaining the $\mathrm{CWC}$ communities living in the fjord. Most studies were carried out in the central-southern part of Patagonia (from Penas Gulf to Cape Horn, S 46.50 $-\mathrm{S} 55.55^{\circ}$ ), while studies performed in the northern area (from Puerto Montt to San Rafael Lagoon, S 41.20 - S $46.40^{\circ}$ ) mainly focused on selected microzooplankton taxa in the upper water column, on bulk measurements of zooplankton biomass, or on the carbon flow through the pelagic food web (e.g. Palma, 2008 and references therein; Villenas, Soto \& Palma, 2009; González et al., 2010, 2011; Palma et al., 2011; Sánchez, González \& Iriarte, 2011). Other studies addressed the physical oceanographic processes and their effect on zooplankton distribution (e.g. Marín \& Delgado, 2009; Castro et al., 2011) and their relationship with zoo- and ichthyoplankton growth and feeding (Landaeta et al., 2015a,b). Recent studies have investigated zooplankton migration patterns by acoustic backscatter and vertical velocity profiles (Valle-Levinson et al., 2014; DíazAstudillo, Cáceres \& Landaeta, 2017; Pérez-Santos et al., 2018). The information on 
125

126

127

128

129

130

131

132

133

134

135

136

137

138

139

140

141

142

143

144

145

146

147

148

149

150

151

152

153

154

155

156

157

zooplankton diversity and migration patterns is, however, still very fragmentary and the linkage between the abundance of CWC and zooplankton supply in Comau Fjord remains unknown.

In this study, we aim to describe the diel, vertical, and seasonal distribution of mesozooplankton groups of Comau Fjord, with a focus on the dominating taxa, particularly those that migrate and are more likely to aggregate. Samples were collected at day and night hours with vertical net hauls through the whole water column in spring, summer, autumn and winter. They were processed with a high-resolution image analysis system (ZooScan, Gorsky et al. 2010). The zooplankton taxa were identified using EcoTaxa 2.0 (Picheral, Colin \& Irisson, 2017), allowing to assess the influence of seasonal environmental changes on zooplankton dynamics, and the food naturally available to CWC.

\section{Materials \& Methods}

Field work was carried out in Comau Fjord, Northern Patagonia, Chile (Fig. 1). Zooplankton was sampled four times at a fixed station $\left(42^{\circ} 14.95 \mathrm{~S}, 72^{\circ} 28.83 \mathrm{~W}\right)$ in central Comau Fjord: in austral spring ( $28^{\text {th }}$ September 2016 ; three days before spring tide-new moon), summer (17 $7^{\text {th }}$ January 2017; two days after spring tide-full moon), autumn ( $7^{\text {th }}$ May 2017; three days before spring tidefull moon), and winter (29th July 2017; one day before neap tide), during both day (noon) and night (midnight). Samples were collected with a $70 \mathrm{~cm}$-diameter Nansen closing net (mesh size: $100 \mu \mathrm{m}$ ) equipped with a non-filtering cod end. Vertical hauls were carried out at $0.45 \mathrm{~m} \mathrm{~s}^{-1}$ to sample the depth strata 0-50-100-200-300-400-450 m. Immediately after the collection, the samples were sieved through a $50 \mu \mathrm{m}$ mesh and preserved in $4 \%$ borax-buffered formaldehyde for laboratory analyses. After every zooplankton haul, a CTD multi-probe (SBE 19plusV2 Profiler - with RS 232 Interface, Sea-Bird Electronics Inc.) was deployed from the surface to the bottom, measuring conductivity, temperature, oxygen, $\mathrm{pH}$ and chlorophyll $a(\mathrm{Chl} a)$ fluorescence.

In the laboratory, fixed zooplankton samples were washed with fresh water and prepared for analysis with a ZooScan digital imaging system (Grosjean et al., 2004; Gorsky et al., 2010). ZooScan (CNRS patent, www.hydroptic.com) provides a quick and reliable method for the analysis of preserved plankton samples, storing digitized images for later examination, reprocessing and dissemination. Concentrated samples were subsampled with a Folsom plankton splitter to avoid images being cluttered with more than approximately 1000-1500 individuals. Up to six binary splitting steps were carried out (corresponding to a minimum $1 / 64^{\text {th }}$ fraction of the original sample). Routinely, the two final splits were scanned with ZooScan yielding images of 
158

159

160

161

162

163

164

165

166

167

168

169

170

171

172

173

174

175

176

177

178

179

180

181

182

183

184

185

186

187

188

189

190

191

192

2400-dpi resolution $(14200 \times 22700$ pixels). The hinged base of the ZooScan allowed the recovery of the complete undamaged subsample, which was later stored in $70 \%$ ethanol for archiving. Most overlapping individuals on the scanning surface were manually separated to ensure an even distribution before scanning. Image analysis was performed with the software ZooProcess (Gorsky et al., 2010), a plug-in for the image processing and analysis software ImageJ (Schneider, Rasband \& Eliceiri, 2012). The processing involved (1) the automatic subtraction of background noise, (2) the automatic thresholding and detection of objects, and (3) the automated storage of detected objects in separate images ("vignettes"). Below $300 \mu \mathrm{m}$, organisms were often too blurred to be identified. Thus, the ZooScan detection limit was set at the standard of $300 \mu \mathrm{m}$ so that detected zooplankton sizes ranged from 0.3 to $59 \mathrm{~mm}$. The automatic processing of the scans was successful in $75-80 \%$ of the cases where vignettes with one individual were obtained. However, despite the manual separation, some individuals overlapped, resulting in vignettes with two or more objects. These objects on the pictures were manually separated using the "separation with mask" tool of the ZooProcess software. Separated vignettes were stored, while the original vignette, containing multiple objects was eliminated from the database to avoid duplicate counts. In some cases, the separation of individuals was not possible as cutting the vignette would mean losing information about the morphology of the organisms (i.e. cutting overlapping urosomes from two different copepods or small copepods embedded in cnidarians). Overall, the contribution of vignettes with multiple objects that could not be separated was always $<10 \%$ of the total amount of vignettes.

Vignettes were subjected to the semi-automated taxonomic classification in EcoTaxa 2.0 (Picheral, Colin \& Irisson, 2017). This web-based machine learning application uses training sets of expert-identified taxa and random forest classification to automatically identify and sort the objects. Although EcoTaxa contains more than 160 million objects on its server, no ZooScan training set was available for Patagonian waters. Therefore, manual identification of individuals on a subset of the images was first necessary to train an initial model, which was later used by the system to classify the scanned organisms. The initial learning set with Patagonian organisms improved progressively its prediction by sorting more objects into the given categories. This produced the final learning set for the classification of the entire image data set. At the end, all classified objects were individually validated to assure a correct classification. The organisms were classified to the lowest possible taxonomic level; for most copepods this was the family level. However, small calanoid copepods $(<1.5 \mathrm{~mm})$ were not distinguishable on family level and were thus comprised as one category: "Calanoids $(<1.5 \mathrm{~mm})$ " including five groups (copepodites (all calanoid taxa, $<1 \mathrm{~mm}$ ), Clausocalanidae, Microcalanidae, small Calanidae (Neocalanus spp.) and Paracalanidae). Developmental stages were included in the corresponding taxon as long as 
193 they were clearly identifiable. Only for calanoid copepods, the classification of some

194 developmental stages was not clear and therefore, they were included into the category

195 "copepodites", which included developmental stages of different calanoid copepod taxa. The

196 category Cnidaria was constituted by organisms from the class Hydrozoa (mostly medusa and

197 Siphonophorae). Another category contained all images that were out of focus ("bad focus") and

198 likely comprised individuals from all copepod taxa, in total 6,766 vignettes. From the total of

19983,516 vignettes, 23,227 could not be assigned to zooplankton taxa, but were labelled as

200 "detritus", "feces", "fiber", "leg" "bubble" and "other" and were not considered in our analyses.

201 ZooProcess provides information about the length and width of each object, allowing the

202 calculation of its volume as a proxy for its biomass (Gorsky et al., 2010). The program

203 automatically fits an ellipse around the object, from which the major and minor axis and volume

$204(\mathrm{~V})$ is computed:

$205 V\left(\mathrm{~mm}^{3}\right)=\frac{4}{3} \times \pi \times \frac{\text { major axis }(\mathrm{mm})}{2} \times\left(\frac{\text { minor axis }(\mathrm{mm})}{2}\right)^{2}$

206 Biovolume (BV) was then calculated as the sum of the volumes of all objects $(\Sigma \mathrm{V})$ divided by

207 the fraction of the sample (e.g., $\mathrm{F}=1 / 64)$ and by the volume filtered by the Nansen net $\left(\mathrm{V}_{\mathrm{N}}\right)$ :

$B V\left(\mathrm{~mm}^{3} / \mathrm{m}^{3}\right)=\frac{\left[\frac{\Sigma V\left(\mathrm{~mm}^{3}\right)}{F}\right]}{V_{N}\left(\mathrm{~m}^{3}\right)}$

$\mathrm{V}_{\mathrm{N}}$ was calculated as:

210

$V_{N}\left(m^{3}\right)=\left[\pi \times\left[\frac{\text { net diameter }(m)}{2}\right]^{2}\right] \times$ depth interval $(m) \times$ filtration efficiency

211 where filtration efficiency was assumed as the theoretical 100\% efficiency (value $=1$ ).

212 Flowmeter readings were not used because the speed of the net haul was below the measuring

213 range of the mechanical flowmeter.

214 For the estimation of biomass, a regression between the dry mass (DM) of a specimen and its

215 body area $\left[\mathrm{DM}(\mu \mathrm{g})=\left(a A^{b}\right)\right]$ was used (Hernández-León \& Montero, 2006; Lehette \&

216 Hernández-León, 2009), where $A$ is the area $\left(\mathrm{mm}^{2}\right)$ of each scanned individual. The regression

217 required different conversion factors depending on the organism, as for instance, gelatinous

218 zooplankton with high water content may not be compared to crustaceans or echinoderms

219 (Table 1). Such coefficients have been successfully published in previous studies for mid-latitude

220 shelf areas (Marcolin, Gaeta \& Lopes, 2015) or the Chilean upwelling region (Tutasi \&

221 Escribano, 2020). 
222 The biomass (B) of each taxon was then calculated as the sum of the individual dry masses of the

223 respective taxon $(\Sigma \mathrm{DM})$ divided by the fraction of the sample (e.g., $\mathrm{F}=1 / 64)$ and by the volume

224 filtered by the Nansen net $\left(\mathrm{V}_{\mathrm{N}}\right)$ :

$225 B\left(m g\right.$ drymass $\left./ m^{3}\right)=\frac{\left[\frac{\sum D M(m g)}{F}\right]}{V_{N}\left(m^{3}\right)}$

226 Biovolume and biomass were calculated to obtain the sum of the values of all individuals for a

227 given taxon. In multiple vignettes, the automatic calculation of biovolume and biomass was not

228 possible because of overlapping specimens from different taxa. Then, the organisms were

229 counted manually and biovolume and biomass were estimated by multiplying the mean volume

230 or DM of the given taxon from all automatic calculations by the extra number of multiple

231 vignettes. Groups with large size variability (e.g., chaetognaths, cnidarians or Euchaetidae) were

232 divided into two categories, small (0.003-4.242 $\left.\mathrm{mm}^{3}\right)$ and large (4.243-90.083 $\left.\mathrm{mm}^{3}\right)$ in order to

233 get a better biovolume/biomass assessment.

234 The integrated values of abundance, biovolume and biomass, were calculated down to $400 \mathrm{~m}$

235 water depth for all seasons, taking out the last $50 \mathrm{~m}$ from summer and winter, to make it

236 comparable to the spring and autumn seasons, where samples were collected down to $400 \mathrm{~m}$.

237 The relationships among physicochemical variables and each taxon's abundance were analyzed

238 using a redundancy analysis (RDA). RDA is a constrained ordination procedure which allows the

239 assessment of how much of the variation of one set of response variables (i.e. zooplankton

240 abundances) is explained with another set of variables (i.e. physicochemical variables). The

241 RDA is a multiresponse analysis which summarizes the linear relationships among dependent

242 and independent variables into a matrix followed by a principal component analysis (PCA).

243 Mean values of temperature, salinity, oxygen, and Chl $a$ (log transformed) for the entire water

244 column were used as explanatory variables. RDA was performed in R (R Core Team, 2021) by

245 using the $r d a$ function of the vegan package (Oksanen et al., 2019). The problems caused by

246 non-normal distributions in testing the significance of RDA results were solved by a permutation

247 test (10,000 iterations) (Borcard, Gillet \& Legendre, 2011) using the anova.cca function from the

248 vegan package. All abundance data were logarithmically transformed before analysis.

249 The centroid depths (CD) of the zooplankton groups for each sampling event were calculated as:

$250 \mathrm{CD}=\sum\left(p_{k} \mathrm{x} z_{k}\right) / \sum p_{k}$, where $p_{k}$ is the number of organisms in the stratum $k$, and $z_{k}$ is the mean

251 depth of the stratum $k$. CD were calculated for abundance and biovolume -not biomass- to better

252 represent the gelatinous zooplankton groups (e.g. Cnidaria). Due to the lack of replication, these

253 values were compared using a contingency table by means of a Chi-square test, in order to test 
254 the significance of night-day changes in $\mathrm{CD}$. The Chi-square test compares the critical values to

255

256

257

258

259

260

261

262

263

264

265

266

267

268

269

270

271

272

273

274

275

276

277

278

279

280

281

282

283

284

285

286

287 assess their significance according to their degrees of freedom $(\mathrm{df})=(r-1)(c-1)$, where $r$ is the number of rows and $c$ the number of columns in the contingency table. After showing significant day-night differences in $\mathrm{CD}$, a dissimilarity analysis (function simper from vegan package) performed pairwise comparisons of zooplankton taxa and estimated the average contribution of each taxon to the average overall Bray-Curtis dissimilarity. We listed the zooplankton taxa which cumulatively contributed at least to $70 \%$ of the night-day differences observed.

\section{Results}

The physicochemical parameters measured throughout the water column of Comau Fjord showed a stronger seasonal variability in surface waters $(0-50 \mathrm{~m})$ than in deep waters $(50-450 \mathrm{~m})$ (Fig. 2). The temperature profile indicated summer stratification down to $17 \mathrm{~m}$ water depth, followed by surface cooling, breakdown of the thermocline in autumn, and reverse temperature gradients in winter and spring. Accordingly, the surface temperature values were the lowest in winter and spring $\left(8.6-11^{\circ} \mathrm{C}\right)$, and the highest in summer $\left(16.7^{\circ} \mathrm{C}\right)$, getting cooler again in autumn $\left(12^{\circ} \mathrm{C}\right)$. In deeper waters, temperatures were more stable with an average value of $11.4 \pm$ $0.2{ }^{\circ} \mathrm{C}$ (mean $\pm \mathrm{SD}$; Fig. 2A). Salinity was between 10-30 in the upper $20 \mathrm{~m}$ and $32.9 \pm 0.4$ below $20 \mathrm{~m}$ (Fig. 2B). The pH ranged between 8.5 and 7.7 in the upper $50 \mathrm{~m}$ and was $7.9 \pm 0.1$ in deeper waters in all seasons, except for autumn, where we interpret the sudden drop of $\mathrm{pH}$ values as an instrument malfunction (Fig. 2C). Oxygen concentration showed the largest variations in the upper $50 \mathrm{~m}$ during the spring season $\left(137.2-410.5 \mu \mathrm{mol} \mathrm{kg}^{-1}\right)$, while below 100 $\mathrm{m}$ depth it was on average $180 \pm 9.3 \mu \mathrm{mol} \mathrm{kg}{ }^{-1}$ (Fig. 2D). The chlorophyll $a(\mathrm{Chl} a)$

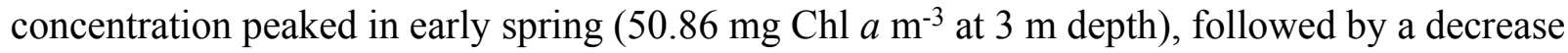
towards the end of the summer and low values through autumn and mid-winter (2.5-5 $\mathrm{mg} \mathrm{Chl} a$ $\mathrm{m}^{-3}$ at 5-10 $\mathrm{m}$ depth) (Fig. 2E). Below $25 \mathrm{~m}$, the concentration of Chl $a$ was $<1.8 \pm 0.5 \mathrm{mg} \mathrm{m}^{-3}$ throughout the year (Fig. 2E).

The zooplankton community exhibited large seasonal and diel differences. Abundance, integrated over the upper $400 \mathrm{~m}$ of the water column (individuals $\mathrm{m}^{-2}$ ) showed the highest values in spring and the lowest during autumn for both day and night (Fig. 3A). The integrated biovolume $\left(\mathrm{cm}^{3} \mathrm{~m}^{-2}\right)$ and biomass $\left(\mathrm{g}\right.$ dry mass $\mathrm{m}^{-2}$ ) showed a different pattern with the highest values in summer and the lowest in autumn and winter (Fig. 3B, C). Diel differences in integrated abundances generally showed higher values during the day than at night, except for autumn (Fig. 3A). Diel differences in integrated biovolume and biomass were surprisingly large, 
288

289

290

291

292

293

294

295

296

297

298

299

300

301

302

303

304

305

306

307

308

309

310

311

312

313

314

315

316

317

318

319

320

321

with generally higher values during the night, except for spring (Fig. 3B, C), indicating that during daytime, particularly in spring, zooplankton was more numerous but smaller in size.

Overall, the centroid depth dissimilarity analysis showed that in spring, fewer taxa contributed to the significant day-night differences (Chi-square $\operatorname{Pr}<2.2 \mathrm{e}^{-16}, \mathrm{p}<0.001$ ) both in abundance and biovolume, while in summer and autumn the number of contributing zooplankton groups increased (Fig. 4). The zooplankton vertical distribution showed that abundance exhibited the highest values during day and night in the 0-50 m layer at all seasons, with the exception of autumn during day time, where abundances showed low values throughout the water column (Fig. 5A). The lowest abundances were found in $>300 \mathrm{~m}$ depth in spring, summer and winter, and in 50-100 $\mathrm{m}$ depth in autumn during day and night time (Fig. 5A). The highest biovolume and biomass daytime values were observed in 0-50 $\mathrm{m}$ and 100-200 $\mathrm{m}$ water depth in spring and summer, and in 100-300 $\mathrm{m}$ in autumn. However, in winter, daytime biovolume and biomass were similarly low throughout the entire water column (Fig. 5B, C). At night, the highest biovolume and biomass values were found at the surface $(0-50 \mathrm{~m})$ in all seasons. The lowest biovolume and biomass values were found in $>300 \mathrm{~m}$ depth in spring and summer, in 50-100 $\mathrm{m}$ and 200-300 m depth in autumn and in $>50 \mathrm{~m}$ depth in winter (Fig. 5B, C).

The taxonomic composition greatly differed when considering biovolume and abundance (Fig. 6, 7A; biovolume - not biomass — was used to better represent the gelatinous taxa). Copepoda were generally the dominant group, constituting $20-70 \%$ of the total biovolume, and $64-81 \%$ of the total abundance. Within the copepod community, individuals smaller than $1.5 \mathrm{~mm}$ included (a) copepodites and adults of small calanoid genera, such as Clausocalanidae, Microcalanidae, Neocalanidae and Paracalanidae; (b) cyclopoids of the genera Oithona and Oncaea; (c) harpacticoids; and (d) nauplii. These small copepods accounted for $58-86 \%$ of the total abundance within the copepod community. Overall, 14 out of 41 taxa contributed $45-98 \%$ of the total biovolume and $45-86 \%$ of the total zooplankton abundance (Fig. 6). The other 27 taxa were constituted by copepods (Acartiidae, Aetideidae, Calanoida (non-identifiable), Candaciidae, Centropagidae, Copepoda (non-identifiable), Eucalanidae, Heterorhabdidae, Lucicutiidae, Oncaeidae, Pontellidae, Rhincalanidae), Actinopterygii (eggs and larvae), Appendicularia, Ascidiacea (larvae), Brachiopoda (larvae), Bryozoa (larvae), Cirripedia (nauplii and cypris), Cladocera, Decapoda (larvae), Echinodermata (larvae), eggs, Isopoda, Nemertea (larvae), Platyhelminthes (larvae), Polychaeta (larvae) and non-identifiable organisms.

The contribution of groups other than copepods to the total zooplankton community differed regarding biovolume and abundance. For biovolume, Cnidaria (2-23\%) and Mysida (1-21\%) constituted a large part of the zooplankton community, followed by Chaetognatha (3-15\%). 
322 Metanauplii and calyptopis stages of Euphausiacea were found mostly in spring and summer,

323 accounting for $0-7 \%$ of the total biovolume. A single adult specimen found during winter in $0-50$

$324 \mathrm{~m}$ water depth at night raised the total biovolume of this taxon to $65 \%$. Regarding abundance,

325 copepod nauplii (2-9\%, with their maximum in spring and minimum in autumn) and

326 Appendicularia (0.4-6\%) were the second and third most abundant groups after Copepoda,

327 respectively. The fourth most abundant group differed among seasons: Echinodermata larvae

328 (5\% in spring), Mollusca larvae (2-5\% in summer, 3-9\% in autumn), Ostracoda (4-5\% in

329 autumn) and Bryozoa larvae (2-10\% in winter). Across all samples and seasons, taxa that

330 represented more than 5\% of total biovolume were Cnidaria (13\%), Calanidae (12.9\%), Mysida

331 (12.7\%), Metridinidae (12.6\%), Chaetognatha (9.6\%) and Euchaetidae (8.7\%). The most

332 abundant groups with more than $5 \%$ of the total abundance were Harpacticoida (14.0\%),

333 Cyclopoida (9.1\%) and Metridinidae (8.4\%) (Fig. 6, 7A).

334 The integrated abundance of small and large copepods and chaetognaths showed the highest

335

336

337

338

339

340

341

342

343

344

345

346

347

348

349

350

351

352

353

354

355

356

abundance in spring and generally low values in autumn and winter (Table 2). Highest abundances of copepod nauplii and cnidarians were found in early spring with a minimum in autumn and raising up again in late-winter. Mysida presented a stable abundance throughout the year with a minimum in summer. These groups clearly presented different vertical distributions (Fig. 7). Metridinidae, a family of large copepods with high biovolume and abundance, resided generally above $200 \mathrm{~m}$, exhibiting a peak between 100-200 m during the day. At night, 74\% of their abundance and 77\% of their biovolume were found in the upper $50 \mathrm{~m}$ (Fig. 7B). On average, larger individuals $\left(0.62 \pm 0.3 \mathrm{~mm}^{3}\right.$; average size $\left.\pm \mathrm{SD}\right)$ were found in $100-200 \mathrm{~m}$ waters during the day and night. In spring, a significant proportion of the Metridinidae was found during the day in shallow waters where smaller individuals $\left(0.14 \pm 0.08 \mathrm{~mm}^{3}\right)$ were observed. At nighttime, a fraction of those large and small individuals residing at intermediate waters were found also in shallow waters (Fig. 8A). The Calanidae were found mainly in intermediate waters (100-300 $\mathrm{m})$ during daytime, except in spring, where on average larger individuals $(1.37 \pm 0.5$ $\left.\mathrm{mm}^{3}\right)$ resided (Fig $\left.8 \mathrm{~B}\right)$. In spring, small specimens of Calanidae $\left(0.30 \pm 0.003 \mathrm{~mm}^{3}\right)$ were found in shallow waters also during daytime (Fig 8B). At nighttime, half of the population ( $61 \%$ and $54 \%$ of their abundance and biovolume, respectively) were present in shallow waters. In autumn, however, the whole population stayed between 100-400 m. Despite the low number of Calanidae found at shallow waters, they contributed considerably to the biovolume in these layers (Fig. 6). Euchaetidae showed higher abundance and biovolume in the deep part of the water column during day time (100-450 m), ascending to shallower waters at night (Fig. 7I). Small copepods of the taxa Harpacticoida and Cyclopoida were very abundant, but, as expected, they only represented a small fraction of the total biovolume. Harpacticoida were distributed through the

Peer) reviewing PDF | (2021:08:64543:2:1:NEW 24 Dec 2021) 
357

358

359

360

361

362

363

364

365

366

367

368

369

370

371

372

373

374

375

376

377

378

379

380

381

382

383

384

385

386

387

388

389

whole water column (Fig. 7D). Cyclopoida were mainly present in the upper $50 \mathrm{~m}$ during day and night in all seasons (Fig. 7H). Cnidarians were overall not very abundant, but constituted an important fraction of the biovolume, especially in 200-300 $\mathrm{m}$ depth during day in all seasons, and 50-100 m depth during day time in summer and autumn. Their highest abundances were generally found in 0-50 $\mathrm{m}$ during day and night, while higher biovolumes were detected in deeper layers 200-450 m (Fig. 7E). Throughout the year, Mysida were mainly present in $>200 \mathrm{~m}$ depth during the day, accounting for $52-100 \%$ of its abundance and $89-100 \%$ of its biovolume. In spring, at night a high proportion of their abundance and biovolume were found in shallow waters while in summer only a fraction of their abundance was found in 0-50 m. In autumn and winter the shallowest depth mysids were found was up to $50 \mathrm{~m}$ both during day and night (Fig. $7 \mathrm{~F}$ ). Chaetognatha presented the highest abundances in the 0-50 $\mathrm{m}$ water depth during day and night in all seasons. Their biovolume, however, peaked at 100-300 $\mathrm{m}$ during day and at 0-50 m during night (Fig. 7G).

Overall, the four predictor variables (fluorescence ( $\mathrm{Chl}$ a), oxygen, temperature, salinity) explained $44.3 \%$ and $33.69 \%$ of the total variation in abundance and biovolume, respectively (Fig. S1). The first axis of the RDA explained 34.15\% (abundance) and 25.4\% (biovolume) of the total variation while the second axis only accounted for $10.15 \%$ (abundance) and $8.29 \%$ (biovolume). Relationships between the parameters and the first RDA axis were highest for Chl a, while temperature was related to the second RDA axis. For both abundance and biovolume the main differences were observed between day and night samples in shallow waters $(0-50 \mathrm{~m})$, during spring and summer. The abundance and biovolume of the major zooplankton groups were positively influenced by $\mathrm{Chl} a$ concentration, except for mysids and ostracods, while temperature did not seem to have a strong influence on the majority of the groups, except for the large zooplankton (amphipods, Euphausiacea and euphausiids) (Fig. S1).

\section{Discussion}

\section{Physicochemical properties and mesozooplankton seasonal dynamics}

The physicochemical observations in our study are consistent with earlier descriptions from Comau Fjord, a temperate fjord connected to the Pacific Ocean by the Chacao Channel and Ancud Gulf. Comau Fjord has an estuarine circulation and is characterized by a strong pycnocline, where surface waters $(0-50 \mathrm{~m})$ present higher variability than the deeper and quasihomogeneous water layer (Fig. 2). Clear differences were observed in temperature, $\mathrm{pH}$, oxygen and Chl $a$ in relation to the season, likely caused by the strong seasonal variability in solar 
390

391

392

393

394

395

396

397

398

399

400

401

402

403

404

405

406

407

408

409

410

411

412

413

414

415

416

417

418

419

420

421

422

423

424

radiation (maximum between spring and summer), precipitation and river discharge (maximum in late autumn and winter) (González et al., 2010).

Pronounced seasonality of environmental variables often results in high biological production and are associated to seasonal changes in the holoplankton community (Mauchline, 1998; Balbontín \& Bustos, 2005; Aracena et al., 2011), and meroplankton abundance (Ladah et al., 2005; Landaeta \& Castro, 2006). In Comau Fjord, a thermal inversion of the surface water (0-50 $\mathrm{m}$ ) in winter is visible (Fig. 2), probably due to heat loss in the surface layer caused by winds and the discharge of cold freshwater from rivers and glaciers (Silva, Calvete \& Sievers, 1997). Later in the year, the thermal density stratification stabilizes the water column, triggering spring phytoplankton blooms (Iriarte et al., 2007), which usually follow rain events and thus the input of nutrients. This leads to a strong increase in $\mathrm{Chl} a$ (Fig. 2E). As shown by previous studies in the area (Palma \& Silva, 2004; Vargas et al., 2008; González et al., 2010), this peak in Chl $a$ was most likely due to blooming chain-forming diatoms. The high phytoplankton biomass is expected to be grazed predominantly by copepods, increasing their biomass and establishing the classical diatom-to-zooplankton food web (Palma \& Silva, 2004; Vargas et al., 2008; González et al., 2010). Accordingly, the population dynamics of copepods in this study followed the phytoplankton seasonal cycle, with the highest abundance in spring, associated with the maximum concentration in phytoplankton (Table 2). At this time, copepod nauplii and young stages of calanoid copepods, which are indicative of intense zooplankton reproduction, accounted for a large proportion of the zooplankton community. Considering that copepods are the main food source for cnidarians and chaetognaths (Palma \& Kaiser, 1993), the higher abundance of carnivorous zooplankton occurring in spring (Table 2) can be attributed to the large copepod abundance at this time of the year. In summer, biovolume and biomass reached their maxima (Fig. 3), which together with a lower abundance, suggests the presence of larger individuals or different groups including species with larger individuals. Subsequently, in autumn and winter, zooplankton abundance, biovolume and biomass decreased. At this time, primary production should be low, as reflected by low Chl $a$ values (Fig. 2E), and likely zooplankton growth was limited by food availability (Escribano et al., 2007). The overall decline in copepod abundance from spring to winter may be explained by the decrease in phytoplankton occurrence and the increasing predation pressure exerted by carnivorous zooplankton. In winter, the plankton in the fjord typically shifts towards a microbial loop based community grazed by heterotrophic nanoflagellates, which become the main mesozooplankton prey (Vargas et al., 2008; González et al., 2010) however, this does not support a high secondary production.

The northern part of the Chilean fjord region, the area between Puerto Montt and Guafo Mouth, represents the most productive area of Patagonia in terms of primary production and zooplankton 
425

426

427

428

429

430

431

432

433

434

435

436

437

438

439

440

441

442

443

444

445

446

447

448

449

450

451

452

453

454

455

456

457

458

459

biomass (Palma, 2008). In contrast, the phytoplankton production in the southern area is low due to the stronger influence of glaciers, resulting in cold, fresh and turbid waters (Palma \& Rosales, 1997; Palma \& Silva, 2004; Iriarte et al., 2007; Palma, 2008), and consequently low zooplankton survival and growth (Giesecke et al., 2019). Previous studies described ranges for zooplankton biovolume, expressed as the plankton wet volume, of 65 to more than $1386 \mathrm{ml}$ zooplankton 1000 $\mathrm{m}^{-3}$ outside Comau Fjord, in the Inner Sea off Chiloé island (Palma, 2008). This is in line with the present results (250-1500 $\mathrm{ml}$ zooplankton $1000 \mathrm{~m}^{-3}$ ), showing an especially high biovolume during summer. Palma \& Rosales (1997) also found the highest values of zooplankton biovolume in the northern part (interior of Reloncaví Fjord and Ancud Gulf) with values that ranged between 56 and $1626 \mathrm{ml}$ zooplankton $1000 \mathrm{~m}^{-3}$, but a low zooplankton biovolume in the inner of Comau Fjord. The observed variations may potentially be due to (a) interannual differences with a much lower Chl $a$ concentration during the same season of their year of study (Ramírez, 1995); and/or (b) methodological and analytical differences, e.g. different sampling gears and proxies for biomass estimation (i.e. measurement of zooplankton wet volume vs. image analysis in this study). Moreover, the vertical hauls used in this study may most likely underestimate the abundance of very motile organisms able to avoid the net, such as adult euphausiids, megalopae of Munida gregaria or large fish larvae, which are also important in terms of density and biomass across west Patagonia (Antezana, 1999).

In fjord systems, oceanographic processes such as estuarine circulation, tidal mixing or water column stratification may influence the composition and abundance of zooplankton communities (Palma \& Silva, 2004; Sánchez, González \& Iriarte, 2011). Overall, copepods were the main contributors to the total biomass and biovolume of the zooplankton community, especially during summer (69-78\%). This is in agreement with previous studies showing that in Chilean fjords, planktonic crustaceans, such as copepods and euphausiids, have the highest abundances and biomasses, followed by chaetognaths and gelatinous plankton (Defren-Janson, SchnackSchiel \& Richter, 1999; Palma \& Silva, 2004). Copepods are the most abundant and diverse component of marine zooplankton worldwide (Mauchline, 1998), and the abundance of small copepods $(<1.5 \mathrm{~mm}$ ) generally surpasses the abundance of larger ones (Fransz, 1988; Gallienne \& Robins, 1998; Gallienne, Robins \& Woodd-Walker, 2001). Similarly, small copepods accounted for $58-86 \%$ of the total copepod community in the present study. Another important contributor to zooplankton communities in Chilean fjords is the euphausiid Euphausia vallentini. The present study revealed young stages of euphausiids during spring and summer but only one adult specimen in winter, indicating that euphausiids are present in Comau fjord, but were not caught efficiently in our samples. This is likely related to the small volume filtered by our net, the patchy distribution of E. vallentini, and their ability of avoiding slow nets (Brinton, 1962). 
460 Like euphausiids, mysids can form dense swarms, making them a potential food resource for a

461

462

463

464

465

466

467

468

469

470

471

472

473

474

475

476

477

478

479

480

481

482

483

484

485

486

487

488

489

490

491

492

wide range of organisms, from predatory fishes to benthic CWC. Despite their important contribution to the total zooplankton biovolume in deep waters (Fig. 6), poor attention has been given to their presence in Chilean Patagonia. To our knowledge, there are only two studies describing mysids in this area: Guglielmo \& Ianora (1997) found that the most abundant species for the Strait of Magellan is the deep-dwelling Boreomysis rostrata; Díaz-Astudillo, Cáceres \& Landaeta (2017) found higher abundances of mysids during night and inside the Reloncaví Fjord and Gulf of Ancud. Thus, this study constitutes the first record of mysids in Comau Fjord.

\section{Zooplankton diel vertical distribution and migration}

Biological processes (e.g. diel vertical migration, predator avoidance, location of food patches and mating), together with oceanographic processes (e.g. estuarine circulation or water column stratification) are mechanisms by which the underlying zooplankton behavior present high spatial heterogeneity (Folt \& Burns, 1999). In the present study, zooplankton abundance, biovolume and biomass significantly differed between day and night. These differences were probably due to the high patchiness and the vertical distribution the zooplankton exhibited during day and night, especially by larger zooplankton individuals, those able to form swarms (i.e. mysids and euphausiids) and migrate (Fig. 7B-I). For instance, Euchaetidae, Euphausiacea, Metridinidae and Mysida, four of the larger and most important zooplankton groups, changed their centroid depth between day and night contributing to $30-40 \%$ of the difference in abundance and 30-38\% in biovolume (Fig. 4). To a lesser extent, small organisms, e.g. Appendicularia, Clausocalanidae and Copepoda (nauplii) also contributed to the day-night differences, especially in summer and autumn, however, their contribution was lower (0-29\%) in comparison to larger zooplankton organisms.

Diel Vertical Migration (DVM) is usually associated with differences in light intensity within the photic zone, taking place periodically in $24 \mathrm{~h}$ cycles (Brierley, 2014). During daytime, zooplankton organisms migrate to deeper, darker waters to avoid visual predators, such as fishes, while they come to the surface for feeding at night (Hays, Webb \& Frears, 1998). In Comau Fjord, DVM seemed to be related to the size of the zooplankton. Here, large zooplankton taxa, particularly large copepods, that inhabited the intermediate waters (100-300 $\mathrm{m})$ during daytime ascended to shallow waters at night while small organisms, mainly of cyclopoids and harpacticoids, did not perform a clear DVM (Fig. 7B-I). Throughout the year, Cyclopoida centroid depth fluctuated between 40-85 m water depth and Harpacticoida between 149-254 m water depth. These two copepod groups, however, differed with regard to their vertical

Peer) reviewing PDF | (2021:08:64543:2:1:NEW 24 Dec 2021) 
493 distribution. The highest abundances of cyclopoid copepods were mainly found in the upper 50

$494 \mathrm{~m}$, whereas harpacticoids were found throughout the water column (Fig. 7D).

495 Large individuals from several calanoid copepod taxa (Metridinidae, Calanidae, Euchaetidae), 496 mysids, chaetognaths and cnidarians did perform DVM over $300 \mathrm{~m}$. This agrees with the 497 findings by Hays (1995) that DVM is pronounced in large and pigmented species due to their 498 susceptibility of being perceived by visually orientated predators. Similarly, studies in northern 499 Patagonia have shown that conspicuous zooplankton organisms tend to avoid well illuminated 500 waters (Villenas, Soto \& Palma, 2009). According to Hays, Kennedy \& Frost (2001), large 501 individuals of Metridia usually reside in deep waters, and only a fraction of these ascends to 502 shallow waters at night, whereas smaller individuals stay at the surface continuously. In Comau 503 Fjord, Metridinidae showed the highest values of biovolume and abundance at intermediate 504 depths $(100-200 \mathrm{~m})$ during daytime, but in the surface layer $(0-50 \mathrm{~m})$ at night, indicating that $50577 \%$ of the entire population migrated towards the surface (Fig 7B). In spring, a proportion of the 506 Metridinidae population was found in shallow waters during the day. This was due to the smaller 507 size of the individuals (Fig. 8A) and the higher amount of food available here. Following the 508 same pattern as Metridinidae, larger individuals of Calanidae were found in deeper waters during 509 daytime, whereas small specimens were found in shallow waters also during daytime in spring, 510 where they may not be hunted by visual predators due to their small size. It is possible that those 511 small organisms were individuals of earlier life stages (i.e. small) or species with a smaller size.

512 Euchaetidae also performed DVM where most of the organisms lived continuously in deep 513 waters $(100-450 \mathrm{~m})$ during the day, but a big proportion of the population $(60 \%$ and $53 \%$ of their 514 abundance and biovolume, respectively) migrated to the surface during night, except in winter 515 (Fig. 7I).

516 Mysids accounted for a big proportion (up to 70\%) of the total zooplankton biovolume, 517 especially in spring and winter (Fig. 6). During day, they were generally detected in deep waters 518 (>200 m water depth) and at night they migrated upwards, although their DVM pattern were 519 clear only in spring and summer. At night in spring, both abundance and biovolume were high in 520 the 0-50 m water depth whereas in summer only a high abundance was detected at that water 521 depth. The fact that biovolume peaked at 200-300 $\mathrm{m}$ in summer at night suggested that only 522 small individuals migrated to shallow waters while larger ones stayed at deeper waters (Fig 7F).

523 Chaetognaths were distributed throughout the water column with the highest biovolumes 524 between 100-300 m, during both day and night (Fig. 7G). This is in accordance with the 525 distribution found by Guglielmo \& Ianora (1995) for the Strait of Magellan. A particularly high 526 abundance of chaetognaths in the upper 0-50 m during both day and night and a high biovolume 
527 only at night indicated that bigger individuals migrated to shallow waters at night likely to feed

528 on other organisms. South of Comau Fjord, between Boca del Guafo and the Pulluche Channel,

529 the vertical distribution of cnidarians (i.e. Hydromedusae and Siphonophorae) showed highest

530 abundances in the upper $100 \mathrm{~m}$, specifically in the 20-50 m stratum (Palma, Apablaza \& Soto,

531 2007). In this study, cnidarian highest abundances were found in 0-50 m during day and night.

532 However, biovolume peaked in every season, except for summer, at 200-300 m, indicating that

533 bigger individuals of cnidarians stayed at deeper waters while small individuals resided in

534 shallow waters.

535 In the 50-100 $\mathrm{m}$ water layer a minimum in zooplankton abundance and biomass was found in all 536 seasons (Fig. 5). This "zooplankton gap" could be related to a high concentration of predators in 537 this water depth. In northern Chilean fjords, the high biomasses and abundances of gelatinous 538 organisms are correlated to a decrease in chitinous biomass of other organisms (Palma \& Silva, 539 2004; Villenas, Soto \& Palma, 2009). It is known that chaetognaths and cnidarians can grow at 540 fast rates, forming dense aggregations that seasonally dominate the zooplankton biomass 541 (Casanova, 1999; Brodeur, Sugisaki \& Hunt Jr, 2002) by feeding voraciously on copepods and 542 larvae from other organisms (Lie et al., 1983; Palma \& Rosales, 1997). In our study, biovolume 543 of carnivorous organisms ranged between 18 and $83 \%$ of the total zooplankton in this water 544 layer, reaching particularly high values in summer and autumn (50-83\%) (Fig. 9). These previous 545 evidences suggest that carnivorous organisms may have reduced zooplankton abundance in this 546 depth stratum and predation may play a role in structuring the vertical zooplankton community in 547 Comau Fjord.

548 Mesozooplankton plays an important role in the food web as a food source for many pelagic and 549 benthic organisms (González et al., 2013), including CWC (Gili et al., 2006; Carlier et al., 2009; 550 Mayr et al., 2011). Due to the difficulty of studying CWC in situ, little is known about their 551 natural diet and its availability. In Comau Fjord, CWC thrive also in deeper, naturally acidified 552 waters (Häussermann \& Försterra, 2007; Försterra, Häussermann \& Laudien, 2017). Although 553 the environment is unfavorable, this might be due to the high ingestion rate (e.g. of the CWC 554 Desmophyllum dianthus) which showed a positive impact on their calcification rates, regardless 555 of the seawater pH (Martínez-Dios et al., 2020). Zooplankton abundance and biomass are highly 556 influenced by seasonality. Therefore, CWC must be adapted to differences in food availability, 557 i.e. high zooplankton abundances during spring and summer and low concentrations during 558 autumn and winter. Indeed high growth rates of $D$. dianthus were found in summer (Jantzen et 559 al., 2013b) which may be associated with higher zooplankton availability. In winter, when 560 zooplankton biomass is low, CWC may slow down their metabolism to cope with the lower food 561 availability (Naumann et al., 2011). Only recently, a study confirmed that $D$. dianthus preyed on 
562 medium and large sized calanoid copepods and euphausiids (Höfer et al., 2018). Based on the

563 present DVM data, shallow-dwelling CWC in Comau Fjord might feed on small copepods (e.g.

564 cyclopoid and calanoid) during the day, and on larger organisms during night hours when

565 zooplankton migrates upwards. Deeper-dwelling corals, by contrast, may mainly encounter

566 larger prey, such as mysids or large calanoid copepods (Calanidae, Euchaetidae) and thus may

567 gain enough energy to upregulate their internal $\mathrm{pH}$ in an acidified environment.

568

569

\section{Conclusions}

570

571

572

573

574

575

576

577

578

579

580

581

582

583

584

585

586

587

588

589

590

591

592

593

The seasonal changes of zooplankton over the entire water column showed that abundance peaked in spring, likely due to spring phytoplankton blooms. In summer, biovolume and biomass were the highest and decreased thereafter over time, reaching the lowest values in late autumn and mid-winter. The low concentration of Chl- $a$ during the cold season suggests that primary production was insufficient to support high levels of secondary production. The vertical distribution of zooplankton biovolume and biomass differed between day and night, with a daytime maximum in the 100-200 m water depth and a nighttime maximum in surface waters (0$50 \mathrm{~m}$ ) associated with the diel vertical migration of the calanoid copepod Metridinidae. Overall, copepods were the dominant group of the total zooplankton community with an important contribution of small organisms (individuals $<1.5 \mathrm{~mm}$ ), followed by mysids, chaetognaths and cnidarians (biovolume and biomass), and nauplii and Appendicularia (abundance). The integrated abundance, biovolume and biomass also showed significant differences between daytime and nighttime values. These differences were probably due to the high zooplankton patchiness driven by both biological and oceanographic processes. Diel vertical migration, predation avoidance, location of food patches as well as estuarine circulation, tidal mixing or water column stratification are considered to be the main drivers of the zooplankton distribution in Comau Fjord.

\section{Acknowledgements}

We thank the team of PACOC who contributed to the success of the project. Support during sampling was provided by the scientific and logistic staff from the Fundación San Ignacio del Huinay. Henning Schröder and Manding Suwareh assisted with the sample collection. Thomas Heran, Simon Schöbinger and Jasmin Stimpfle helped with the treatment, analysis and scanning of the samples. Gertraud Schmidt-Grieb provided support in an early phase of the project. 


\section{References}

596

597

598

599

600

601

602

603

604

605

606

607

608

609

610

611

612

613

614

615

616

617

618

619

620

621

622

623

624

625

626

627

628

629

630

631

632

633

634

635

636

637
Antezana T. 1999. Plankton of Southern Chilean fjords: trends and linkages. Scientia Marina 63:69-80. DOI: 10.3989/scimar.1999.63s169.

Aracena C, Lange CB, Iriarte JL, Rebolledo L, Pantoja S. 2011. Latitudinal patterns of export production recorded in surface sediments of the Chilean Patagonian fjords $\left(41-55^{\circ} \mathrm{S}\right)$ as a response to water column productivity. Continental Shelf Research 31:340-355. DOI: 10.1016/j.csr.2010.08.008.

Balbontín F, Bustos C. 2005. Variabilidad en la Composición y Abundancia del Ictioplancton de Chile Austral, durante Noviembre de 2005: Efectos de la Estratificación de la Columna de Agua. In: Resúmenes Resultados Crucero Cimar-Fiordo 2. 123-132.

Barbier EB. 2017. Marine ecosystem services. Current Biology 27:R507-R510. DOI: 10.1016/j.cub.2017.03.020.

Borcard D, Gillet F, Legendre P. 2011. Canonical Ordination. In: Borcard D, Gillet F, Legendre P eds. Numerical Ecology with R. Springer, New York, 153-226.

Brierley AS. 2014. Diel vertical migration. Current Biology 24:R1074-R1076. DOI: 10.1016/j.cub.2014.08.054.

Brinton E. 1962. Variable factors affecting the apparent range and estimated concentration of euphausiids in the North Pacific. Pacific Science 16:374-408.

Brodeur RD, Sugisaki H, Hunt Jr GL. 2002. Increases in jellyfish biomass in the Bering Sea: Implications for the ecosystem. Marine Ecology Progress Series 233:89-103. DOI: $10.3354 /$ meps 233089 .

Buschmann AH, Niklitschek EJ, Pereda S. 2021. Acuicultura y sus impactos en la conservación de la Patagonia chilena. In: Castilla JC, Armesto JJ, Martínez-Harms MJ eds. Conservación en la Patagonia chilena: evaluación del conocimiento, oportunidades y desafios. Santiago, Chile: Ediciones Universidad Católica de Chile, 367-387.

Carlier A, Le Guilloux E, Olu K, Sarrazin J, Mastrototaro F, Taviani M, Clavier J. 2009. Trophic relationships in a deep mediterranean cold-water coral bank (Santa Maria di Leuca, Ionian sea). Marine Ecology Progress Series 397:125-137. DOI: 10.3354/meps08361.

Casanova JP. 1999. Chaetognatha. In: Boltovskoy D ed. South Atlantic Zooplankton. Backuys Publ., Leiden, 1353-1374.

Castro LR, Cáceres MA, Silva N, Muñoz MI, León R, Landaeta MF, Soto-Mendoza S. 2011. Short-term variations in mesozooplankton, ichthyoplankton, and nutrients associated with semi-diurnal tides in a patagonian Gulf. Continental Shelf Research 31:282-292. DOI: 10.1016/j.csr.2010.09.005.

Defren-Janson K, Schnack-Schiel SB, Richter C. 1999. Mesozooplankton communities in the Magellan region. Scientia Marina 63:43-50. DOI: 10.3989/scimar.1999.63s 143.

Díaz-Astudillo M, Cáceres MA, Landaeta MF. 2017. Zooplankton structure and vertical migration: Using acoustics and biomass to compare stratified and mixed fjord systems. Continental Shelf Research 148:208-218. DOI: 10.1016/j.csr.2017.09.004.

Emerson CW, Roff JC. 1987. Implications of fecal pellet size and zooplankton behaviour to estimates of pelagic-benthic carbon flux. Marine Ecology Progress Series 35:251-257. DOI: $10.3354 /$ meps035251.

Escribano R, Fernández M, Aranís A. 2003. Physical-chemical processes and patterns of 
638

diversity of the chilean eastern boundary pelagic and benthic marine ecosystems: An overview. Gayana 67:190-205. DOI: 10.4067/s0717-65382003000200008.

Escribano R, Hidalgo P, González H, Giesecke R, Riquelme-Bugueño R, Manríquez K. 2007. Seasonal and inter-annual variation of mesozooplankton in the coastal upwelling zone off central-southern Chile. Progress in Oceanography 75:470-485. DOI:

10.1016/j.pocean.2007.08.027.

Fillinger L, Richter C. 2013a. Vertical and horizontal distribution of Desmophyllum dianthus in Comau Fjord, Chile: a cold-water coral thriving at low pH. PeerJ:1-22. DOI: 10.7717/peerj.194.

Fillinger L, Richter C. 2013b. Abundance of Desmophyllum dianthus during expedition Comau2012. In: Alfred Wegener Institute, Helmholtz Centre for Polar and Marine Research, Bremerhaven, PANGAEA,. DOI: https://doi.org/10.1594/PANGAEA.811898.

Folt C, Burns C. 1999. Biological drivers of zooplankton patchiness. Trends in Ecology and Evolution 14:300-305. DOI: 10.1016/S0169-5347(99)01616-X.

Försterra G, Häussermann V, Laudien J. 2017. Animal forests in the Chilean Fjords; discoveries, perspectives, and threats in shallow and deep waters. In: Rossi S, Bramanti L, Gori A, Orejas C eds. Marine Animal Forests. Springer, Cham,. DOI: http://doi-org443.webvpn.fjmu.edu.cn/10.1007/978-3-319-21012-4_3.

Fowler SW, Knauer GA. 1986. Role of large particles in the transport of elements and organic compounds through the oceanic water column. Progress in Oceanography 16:147-194. DOI: https://doi.org/10.1016/0079-6611(86)90032-7.

Fransz HG. 1988. Vernal abundance, structure and development of epipelagic copepod populations of the eastern Weddell Sea (Antarctica). Polar Biology 9:107-114. DOI: 10.1007/BF00442037.

Gallienne CP, Robins DB. 1998. Trans-oceanic characterization of zooplankton community size structure using an optical plankton counter. Fisheries Oceanography 7:147-158.

Gallienne CP, Robins DB, Woodd-Walker RS. 2001. Abundance, distribution and size structure of zooplankton along a $20^{\circ}$ west meridional transect of the northeast Atlantic Ocean in July. Deep-Sea Research II 48:925-949. DOI: 10.1016/S0967-0645(00)00114-4.

Giesecke R, Höfer J, Vallejos T, González HE. 2019. Death in southern Patagonian fjords: copepod community structure and mortality in land- and marine-terminating glacier-fjord systems. Progress in Oceanography 174:162-172. DOI: 10.1016/j.pocean.2018.10.011.

Gili JM, Rossi S, Pagès F, Orejas C, Teixidó N, López-González PJ, Arntz WE. 2006. A new trophic link between the pelagic and benthic systems on the Antarctic shelf. Marine Ecology Progress Series 322:43-49. DOI: 10.3354/meps322043.

González HE, Calderón MJ, Castro L, Clement A, Cuevas LA, Daneri G, Iriarte JL, Lizárraga L, Martínez R, Menschel E, Silva N, Carrasco C, Valenzuela C, Vargas CA, Molinet C. 2010. Primary production and plankton dynamics in the Reloncaví Fjord and the Interior Sea of Chiloé, Northern Patagonia, Chile. Marine Ecology Progress Series 402:13-30. DOI: 10.3354/meps08360.

González HE, Castro LR, Daneri G, Iriarte JL, Silva N, Tapia F, Teca E, Vargas CA. 2013. Land-ocean gradient in haline stratification and its effects on plankton dynamics and trophic carbon fluxes in Chilean Patagonian fjords (47-50 $\left.{ }^{\circ}\right)$. Progress in Oceanography 119:3247. DOI: 10.1016/j.pocean.2013.06.003.

González HE, Castro L, Daneri G, Iriarte JL, Silva N, Vargas CA, Giesecke R, Sánchez N. 2011. Seasonal plankton variability in Chilean Patagonia fjords: Carbon flow through the pelagic 
684

685

686

687

688

689

690

691

692

693

694

695

696

697

698

699

700

701

702

703

704

705

706

707

708

709

710

711

712

713

714

715

716

717

718

719

720

721

722

723

724

725

726

727

728

729

food web of Aysen Fjord and plankton dynamics in the Moraleda Channel basin. Continental Shelf Research 31:225-243. DOI: 10.1016/j.csr.2010.08.010.

Gorsky G, Ohman MD, Picheral M, Gasparini S, Stemmann L, Romagnan JB, Cawood A, Pesant S, García-Comas C, Prejger F. 2010. Digital zooplankton image analysis using the ZooScan integrated system. Journal of Plankton Research 32:285-303. DOI: 10.1093/plankt/fbp124.

Grosjean P, Picheral M, Warembourg C, Gorsky G. 2004. Enumeration, measurement, and identification of net zooplankton samples using the ZOOSCAN digital imaging system. ICES Journal of Marine Science 61:518-525. DOI: 10.1016/j.icesjms.2004.03.012.

Guglielmo L, Ianora A (eds.). 1995. Atlas of Marine Zooplankton. Straits of Magellan. Copepods. Springer-Verlag, Berlin Heiderlberg. DOI: 10.1007/978-3-642-79139-0.

Guglielmo L, Ianora A (eds.). 1997. Atlas of Marine Zooplankton. Strait of Magellan. Amphipods, Euphausiids, Mysids, Ostracods, and Chaetognaths. Springer-Verlag Berlin Heidelberg. DOI: 10.1007/978-3-642-60340-2.

Häussermann V, Försterra G. 2007. Large assemblages of cold-water corals in Chile: a summary of recent findings and potential impacts. Bulletin of Marine Science 81:195-207.

Häussermann V, Försterra G, Laudien J. 2021. Macrobentos de fondos duros de la Patagonia Chilena: Énfasis en la conservación de bosques sublitorales de invertebrados y algas (Hard bottom marobenthos of Chilean Patagonia: emphasis on conservation of sublitoral invertebrate algal forests). In: Castilla JC, Armesto JJ, Martínez-Harms MJ eds. Conservación en la Patagonia chilena: evaluación del conocimiento, oportunidades y desafios. Santiago, Chile: Ediciones Universidad Católica de Chile, 321-344.

Hays GC. 1995. Ontogenetic and seasonal variation in the diel vertical migration of the copepods Metridia lucens and Metridia longa. Limnology and Oceanography 40:1461-1465.

Hays GC, Kennedy H, Frost BW. 2001. Individual variability in diel vertical migration of a marine copepod: Why some individuals remain at depth when others migrate. Limnology and Oceanography 46:2050-2054. DOI: 10.4319/1o.2001.46.8.2050.

Hays GC, Webb PI, Frears SL. 1998. Diel changes in the carbon and nitrogen content of the copepod Metridia lucens. Journal of Plankton Research 20:727-737. DOI: 10.1093/plankt/20.4.727.

Hernández-León S, Montero I. 2006. Zooplankton biomass estimated from digitalized images in Antarctic waters: A calibration exercise. Journal of Geophysical Research 111:1-6. DOI: 10.1029/2005JC002887.

Höfer J, González HE, Laudien J, Schmidt GM, Häussermann V, Richter C. 2018. All you can eat: the functional response of the cold-water coral Desmophyllum dianthus feeding on krill and copepods. PeerJ. DOI: 10.7717/peerj.5872.

Iriarte JL, González HE, Liu KK, Rivas C, Valenzuela C. 2007. Spatial and temporal variability of chlorophyll and primary productivity in surface waters of southern Chile $\left(41.5-43^{\circ} \mathrm{S}\right)$. Estuarine, Coastal and Shelf Science 74:471-480. DOI: 10.1016/j.ecss.2007.05.015.

Iriarte JL, González HE, Nahuelhual L. 2010. Patagonian fjord ecosystems in Southern Chile as a highly vulnerable region: problems and needs. Ambio 39:463-466. DOI: 10.1007/s13280010-0049-9.

Iwasa Y. 1982. Vertical migration of zooplankton : a game between predator and prey. The American Naturalist 120:171-180.

Jantzen C, Häussermann V, Försterra G, Laudien J, Ardelan M, Maier S, Richter C. 2013a. Occurrence of a cold-water coral along natural $\mathrm{pH}$ gradients (Patagonia, Chile). Marine

Peer) reviewing PDF | (2021:08:64543:2:1:NEW 24 Dec 2021) 
730

731

732

733

734

735

736

737

738

739

740

741

742

743

744

745

746

747

748

749

750

751

752

753

754

755

756

757

758

759

760

761

762

763

764

765

766

767

768

769

770

771

772

773

774

775

Biology 160:2597-2607. DOI: 10.1007/s00227-013-2254-0.

Jantzen C, Laudien J, Sokol S, Försterra G, Häussermann V, Kupprat F, Richter C. 2013b. In situ short-term growth rates of a cold-water coral. Marine and Freshwater Research 64:631641. DOI: 10.1071/MF12200.

Ladah LB, Tapia FJ, Pineda J, López M. 2005. Spatially heterogeneous, synchronous settlement of Chthamalus spp. larvae in northern Baja California. Marine Ecology Progress Series 302:177-185.

Landaeta MF, Bustos CA, Contreras JE, Salas-Berríos F, Palacios-Fuentes P, Alvarado-Niño M, Letelier J, Balbontín F. 2015a. Larval fish feeding ecology, growth and mortality from two basins with contrasting environmental conditions of an inner sea of northern Patagonia, Chile. Marine Environmental Research 106:19-29. DOI: 10.1016/j.marenvres.2015.03.003.

Landaeta MF, Castro LR. 2006. Larval distribution and growth of the rockfish, Sebastes capensis (Sebastidae, Pisces), in the fjords of southern Chile. ICES Journal of Marine Science:714724.

Landaeta MF, Contreras JE, Bustos CA, Pérez-Matus A. 2015b. Growth and condition of larval rockfish in a Patagonian fjord-type inlet: role of hydrographic conditions and food availability. Aquatic Ecology 49:573-584. DOI: 10.1007/s10452-015-9547-y.

Lehette P, Hernández-León S. 2009. Zooplankton biomass estimation from digitized images: a comparison between subtropical and Antarctic organisms. Limnology and Oceanography: Methods 7:304-308. DOI: 10.4319/lom.2009.7.304.

Lie U, Magnesen T, Tunberg B, Aksnes D. 1983. Preliminary studies on the vertical distribution of size-fractions in the zooplankton community in Lindås- Pollene, Western Norway. Sarsia 68:65-80. DOI: 10.1080/00364827.1983.10420558.

Liu KK, Atkinson L, Quinones R, Talaue-McManus L. 2010. Carbon and nutrient fluxes in continental margins. Springer-Verlag Berlin Heidelberg. DOI: 10.1007/978-3-540-92735-8.

Maier C, Popp P, Sollfrank N, Weinbauer MG, Wild C, Gattuso JP. 2016. Effects of elevated pCO2 and feeding on net calcification and energy budget of the Mediterranean cold-water coral Madrepora oculata. Journal of Experimental Biology 219:3208-3217. DOI: 10.1242/jeb.127159.

Mann KH, Lazier JRN. 1991. Dynamics of marine ecosystems: biological-physical interactions in the oceans. Oxford, Blackwell Scientific Publications.

Marcolin C da R, Gaeta S, Lopes RM. 2015. Seasonal and interannual variability of zooplankton vertical distribution and biomass size spectra off Ubatuba, Brazil. Journal of Plankton Research 37:808-819. DOI: 10.1093/plankt/fbv035.

Marín VH, Delgado LE. 2009. Diversidad y distribución espacial de copépodos superficiales (010 metros) en la zona costera del mar interior de Chiloé (Cimar 10 Fiordos). Ciencia y Tecnología del Mar 32:95-100.

Martínez-Dios A, Pelejero C, López-Sanz À, Sherrell RM, Ko S, Häussermann V, Försterra G, Calvo E. 2020. Effects of low $\mathrm{pH}$ and feeding on calcification rates of the cold-water coral Desmophyllum dianthus. PeerJ. DOI: 10.7717/peerj.8236.

Mauchline J. 1998. The biology of calanoid copepods. Advances in Marine Biology 33:1-710. Mayr CC, Försterra G, Häussermann V, Wunderlich A, Grau J, Zieringer M, Altenbach A V. 2011. Stable isotope variability in a Chilean fjord food web: implications for N- and Ccycles. Marine Ecology Progress Series 428:89-104. DOI: 10.3354/meps09015.

McCulloch M, Trotter J, Montagna P, Falter J, Dunbar R, Freiwald A, Försterra G, López Correa M, Maier C, Rüggeberg A, Taviani M. 2012. Resilience of cold-water scleractinian corals to

Peer) reviewing PDF | (2021:08:64543:2:1:NEW 24 Dec 2021) 
776

ocean acidification: boron isotopic systematics of $\mathrm{pH}$ and saturation state up-regulation. Geochimica et Cosmochimica Acta 87:21-34. DOI: 10.1016/j.gca.2012.03.027.

Meerhoff E, Castro LR, Tapia FJ, Pérez-Santos I. 2019. Hydrographic and biological impacts of a Glacial Lake Outburst Flood (GLOF) in a Patagonian Fjord. Estuaries and Coasts 42:132-143. DOI: 10.1007/s12237-018-0449-9.

Naumann MS, Orejas C, Wild C, Ferrier-Pagès C. 2011. First evidence for zooplankton feeding sustaining key physiological processes in a scleractinian cold-water coral. Journal of Experimental Biology 214:3570-3576. DOI: 10.1242/jeb.061390.

Navedo JG, Vargas-Chacoff L. 2021. Salmon aquaculture threatens Patagonia. Science 372:695696. DOI: $10.1126 /$ science.abj0016.

Nemoto T. 1970. Feeding pattern of baleen whales in the ocean. In: Steele JH ed. Marine food chains. University of California Press, 551.

Oksanen J, Blanchet FG, Friendly M, Kindt R, Legendre P, McGlinn D, Minchin PR, O'Hara RB, Simpson GL, Solymos P, Stevens MHH. 2019. vegan: Community Ecology Package. R package version 2.5-6.

Palma S. 2008. Zooplankton distribution and abundance in the austral Chilean channels and fjords. In: Silva N, Palma S eds. Progress in the oceanographic knowledge of Chilean interior waters, from Puerto Montt to Cape Horn. Comité Oceanográfico Nacional Pontificia Universidad Católica de Valparaíso, Valparaíso, 107-113.

Palma S, Apablaza P, Soto D. 2007. Diversity and aggregation areas of planktonic cnidarians of the southern channels of Chile (Boca del Guafo to Pulluche Channel). Investigaciones Marinas 35:71-82. DOI: 10.4067/S0717-71782007000200008.

Palma S, Kaiser K. 1993. Plancton marino de aguas Chilenas. Ediciones Universitarias de Valparaíso.

Palma S, Rosales SA. 1997. Sifonóforos epipelágicos de los Canales Australes Chilenos (41³0 - 46 40' S). Ciencia y Tecnología del Mar 20:125-145.

Palma S, Silva N. 2004. Distribution of siphonophores, chaetognaths, euphausiids and oceanographic conditions in the fjords and channels of southern Chile. Deep-Sea Research II 51:513-535. DOI: 10.1016/j.dsr2.2004.05.001.

Palma S, Silva N, Retamal MC, Castro L. 2011. Seasonal and vertical distributional patterns of siphonophores and medusae in the Chiloé Interior Sea, Chile. Continental Shelf Research 31:260-271. DOI: 10.1016/j.csr.2010.04.007.

Pan J, Marcoval MA, Bazzini SM, Vallina M V., Marco SG de. 2013. Coastal marine biodiversity challenges and threats. In: Arias AH, Menendez MC eds. Marine Ecology in a Changing World. CRC Press, 43-67. DOI: 10.1201/b16334-3.

Pantoja S, Iriarte JL, Daneri G. 2011. Oceanography of the Chilean Patagonia. Continental Shelf Research 31:149-153. DOI: 10.1016/j.csr.2010.10.013.

Pérez-Santos I, Castro L, Ross L, Niklitschek E, Mayorga N, Cubillos L, Gutierrez M, Escalona E, Castillo M, Alegría N, Daneri G. 2018. Turbulence and hypoxia contribute to dense zooplankton scattering layers in Patagonian Fjord System. Ocean Science 14:1185-2018. DOI: $10.5194 /$ os-2017-89.

Pérez-Santos I, Garcés-Vargas J, Schneider W, Ross L, Parra S, Valle-Levinson A. 2014. Double-diffusive layering and mixing in Patagonian fjords. Progress in Oceanography 129:35-49. DOI: 10.1016/j.pocean.2014.03.012.

Picheral M, Colin S, Irisson J-O. 2017. EcoTaxa, a tool for the taxonomic classification of images. http://ecotaxa.obs-vlfr.fr. 
822 R Core Team. 2021. R: A language and environment for statistical computing.

823 Ramírez B. 1995. Distribución de la biomasa pigmentaria en los Canales Australes. In: Resúmenes Resultados Crucero Cimar Fiordo 1. 74-75.

825

826

827

828

829

830

831

832

833

834

835

836

Sánchez N, González HE, Iriarte JL. 2011. Trophic interactions of pelagic crustaceans in Comau Fjord (Chile): Their role in the food web structure. Journal of Plankton Research 33:12121229. DOI: $10.1093 /$ plankt/fbr022.

Schneider CA, Rasband WS, Eliceiri KW. 2012. NIH Image to ImageJ: 25 years of image analysis. Nature Methods 9:671-675. DOI: 10.1038/nmeth.2089.

Sievers HA, Silva N. 2008. Water masses and circulation in austral Chilean channels and fjords. In: Silva N, Palma S eds. Progress in the oceanographic knowledge of Chilean interior waters, from Puerto Montt to Cape Horn. Comité Oceanográfico Nacional - Pontificia Universidad Católica de Valparaíso, Valparaíso, 53-58.

Silva N, Calvete C, Sievers HA. 1997. Características Oceanográficas Físicas y Químicas de Canales Australes Chilenos entre Puerto Montt y Laguna San Rafael (Crucero Cimar-Fiordo 1). Ciencia y Tecnología del Mar 20:23-106.

Stich HB, Lampert W. 1981. Predator evasion as an explanation of diurnal vertical migration by zooplankton. Nature 293:396-398. DOI: 10.1038/293396a0.

Tutasi P, Escribano R. 2020. Zooplankton diel vertical migration and downward C flux into the oxygen minimum zone in the highly productive upwelling region off Northern Chile. Biogeosciences 17:455-473. DOI: 10.5194/bg-2019-127.

Urrère MA, Knauer GA. 1981. Zooplankton fecal pellet fluxes and vertical transport of particulate organic material in the pelagic environment. Journal of Plankton Research 3:369-387. DOI: 10.1093/plankt/3.3.369.

Valle-Levinson A, Castro L, Cáceres M, Pizarro O. 2014. Twilight vertical migrations of zooplankton in a Chilean fjord. Progress in Oceanography 129:114-124. DOI: 10.1016/j.pocean.2014.03.008.

Vandromme P, Stemmann L, Garcia-Comas C, Berline L, Sun X, Gorsky G. 2012. Assessing biases in computing size spectra of automatically classified zooplankton from imaging systems: a case study with the ZooScan integrated system. Methods in Oceanography 12:3-21. DOI: 10.5194/bgd-7-9175-2010.

Vargas CA, Martínez RA, González HE, Silva N. 2008. Contrasting trophic interactions of microbial and copepod communities in a fjord ecosystem, Chilean Patagonia. Aquatic Microbial Ecology 53:227-242. DOI: 10.3354/ame01242.

Villenas F, Soto D, Palma S. 2009. Cambios interanuales en la biomasa y biodiversidad de zooplancton gelatinoso en aguas interiores de Chiloé, sur de Chile (primaveras 2004 y 2005). Revista de Biologia Marina y Oceanografia 44:309-324. DOI: 10.4067/s071819572009000200005. 


\section{Table 1 (on next page)}

Regression coefficients between individual dry mass and body area to estimate biomass $\left[\mathrm{DM}(\mu \mathrm{g})=\left(a A^{b}\right)\right]$ for different groups given by Lehette and Hernández-León (2009). Area provides the size range for each category observed in this study 
1 Table 1 Regression coefficients between individual dry mass and body area to estimate biomass

$2\left[\mathrm{DM}(\mu \mathrm{g})=\left(a A^{b}\right)\right]$ for different groups given by Lehette and Hernández-León (2009). Area

3 provides the size range for each category observed in this study.

4

\begin{tabular}{l|ccc} 
Organism & $a$ & $b$ & Area $\left(\mathrm{mm}^{2}\right)$ \\
\hline Actinopterygii (eggs and larvae) & 43.38 & 1.54 & $0.079-1.198$ \\
\hline Appendicularia & 43.38 & 1.54 & $0.056-6.071$ \\
\hline Ascidiacea (larvae) & 43.38 & 1.54 & $0.072-1.652$ \\
Amphipoda & 43.38 & 1.54 & $0.103-59.854$ \\
Brachiopoda (larvae) & 43.38 & 1.54 & $0.193-0.366$ \\
Bivalvia (larvae) & 43.38 & 1.54 & $0.071-2.040$ \\
Bryozoa (larvae) & 43.38 & 1.54 & $0.067-0.240$ \\
Chaetognatha & 23.45 & 1.19 & $0.068-15.935$ \\
Cirripedia (larvae and cypris) & 43.38 & 1.54 & $0.071-0.286$ \\
Cladocera & 43.38 & 1.54 & $0.072-0.455$ \\
Cnidaria & 4.03 & 1.24 & $0.051-95.743$ \\
Copepoda & 43.97 & 1.52 & $0.068-9.177$ \\
Decapoda (zoea) & 43.38 & 1.54 & $0.072-6.733$ \\
Echinodermata & 43.38 & 1.54 & $0.070-0.757$ \\
Euphausiacea & 43.38 & 1.54 & $0.145-461.813$ \\
Eggs & 43.38 & 1.54 & $0.070-1.952$ \\
Gastropoda (larvae) & 43.38 & 1.54 & $0.071-2.266$ \\
Isopoda & 43.38 & 1.54 & $0.073-0.930$ \\
Mysidacea & 43.38 & 1.54 & $0.126-43.504$ \\
Nemertea (pilidium) & 43.38 & 1.54 & $0.082-0.777$ \\
Ostracoda & 43.38 & 1.54 & $0.066-1.270$ \\
Platyhelminthes (larvae) & 43.38 & 1.54 & $0.075-0.162$ \\
Polychaeta (larvae) & 43.38 & 1.54 & $0.068-7.535$ \\
\hline
\end{tabular}

5 


\section{Table 2 (on next page)}

Integrated abundances (ind $\mathrm{m}^{-2}$ ) of the most important zooplankton taxa over the entire water column sampled on four dates throughout a year. 
1 Table 2 Integrated abundances (ind $\mathrm{m}^{-2}$ ) of the most important zooplankton groups over the

2 entire water column sampled on four dates throughout a year.

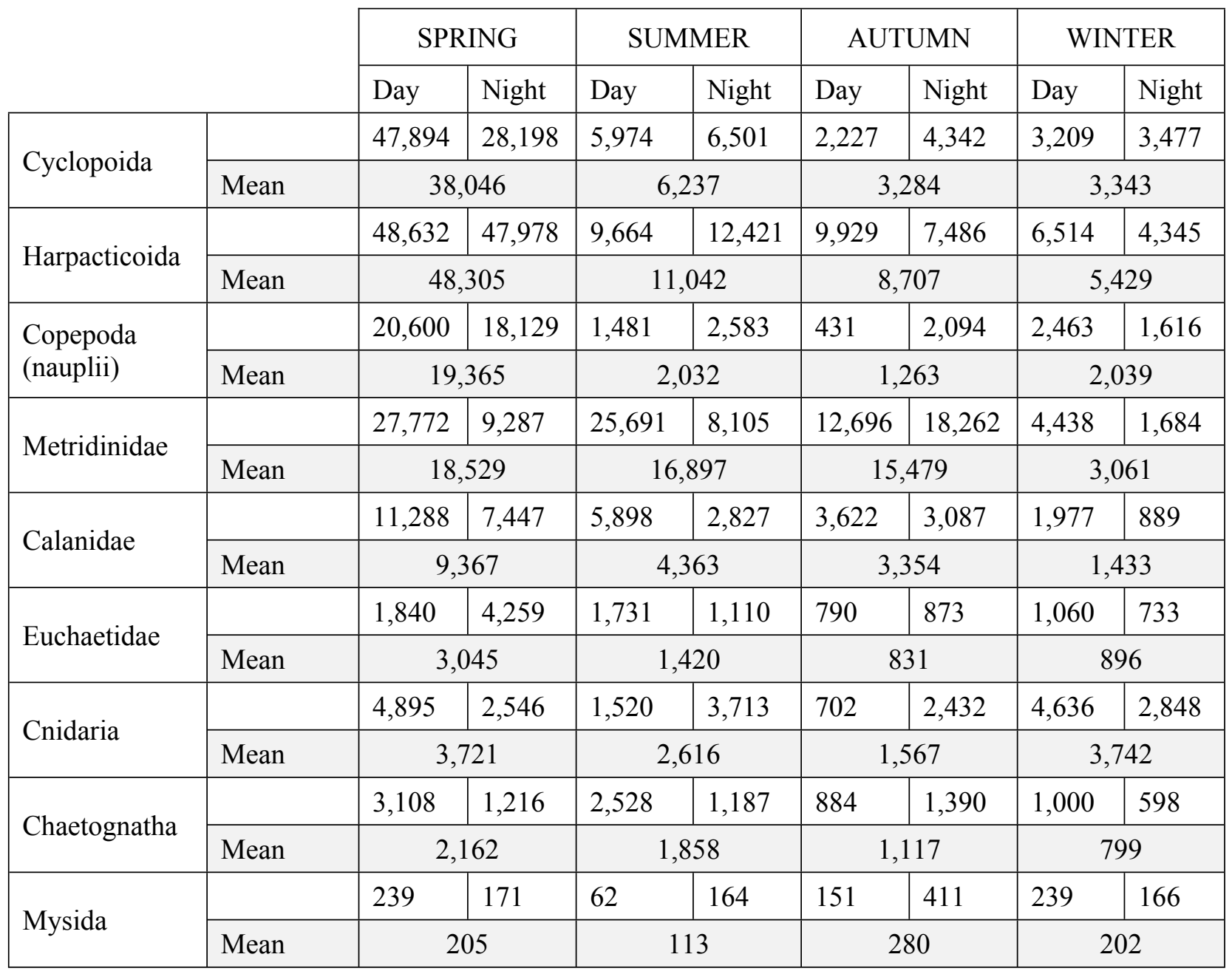




\section{Figure 1}

Study site.

(A) Overview of Chilean Patagonia. Red square denotes area in panel B. (B) Inner Sea off Chiloé island, where Comau Fjord (red dot) is located. (C) Comau Fjord with the bathymetry and location of the station where zooplankton samples were taken (red dot). Adapted from Fillinger \& Richter (2013a). 


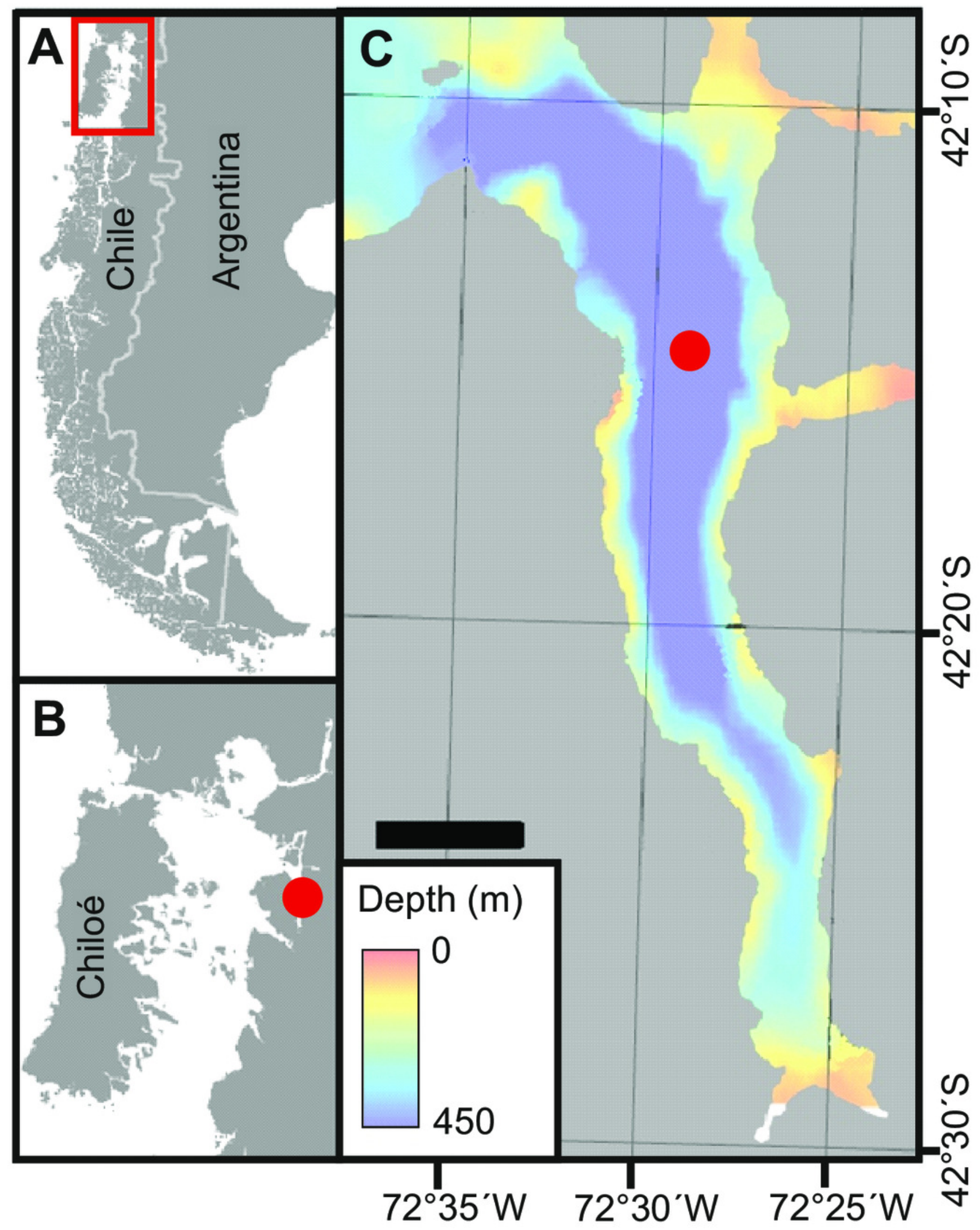


Figure 2

Vertical profiles of physico-chemical parameters of Comau Fjord.

(A) temperature, (B) salinity, (C) pH, (D) oxygen and (E) Chlorophyll-a. Note the break at 100 $\mathrm{m}$ with the different scales above and below.

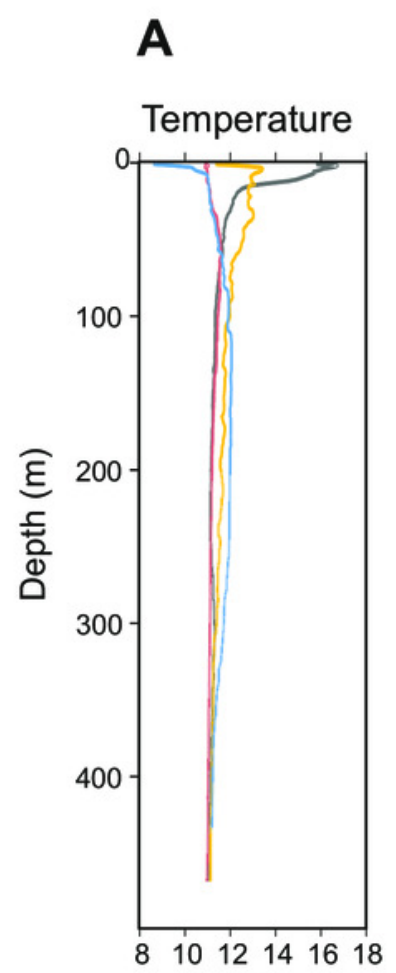

$\left({ }^{\circ} \mathrm{C}\right)$
B

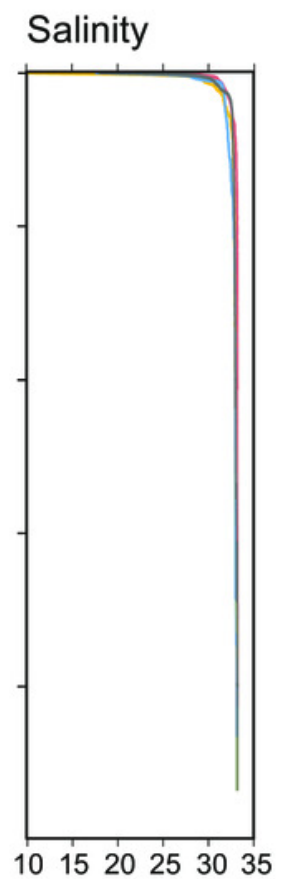

101520253035
D

Oxygen

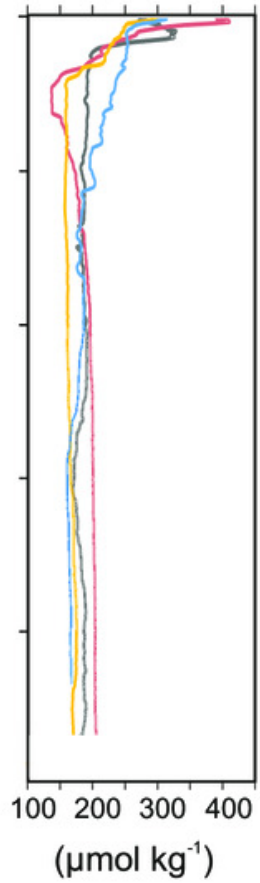

$\mathbf{E}$

Chlorophyll a

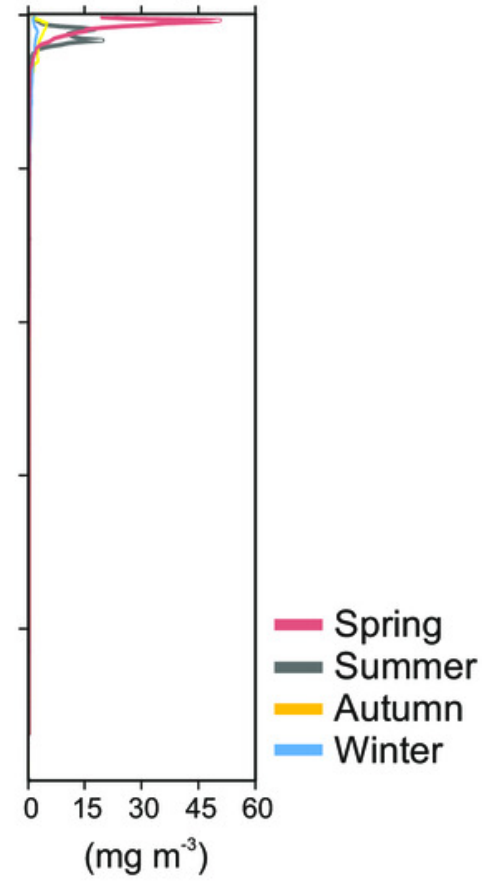


Figure 3

Zooplankton seasonal and diel distribution.

Seasonal distribution of integrated (A) abundance, (B) biovolume and (C) biomass of the zooplankton community during day and night. 

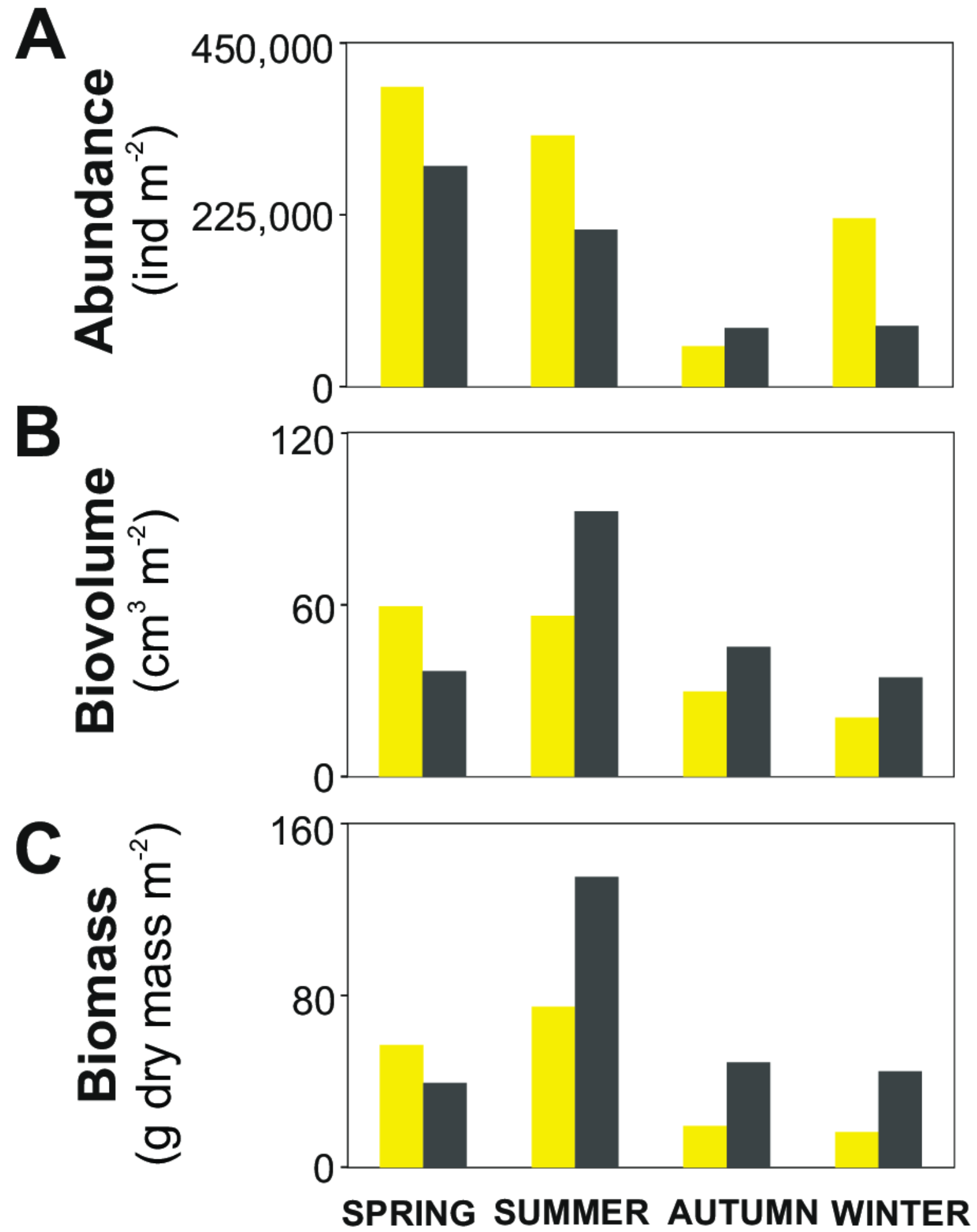

DAY 
Figure 4

Dissimilarity analysis of day-night differences in centroid depth (CD).

Zooplankton taxa which contribute cumulatively to at least $70 \%$ of the day-night differences in $(A)$ abundance $C D$ and $(B)$ biovolume $C D$. 


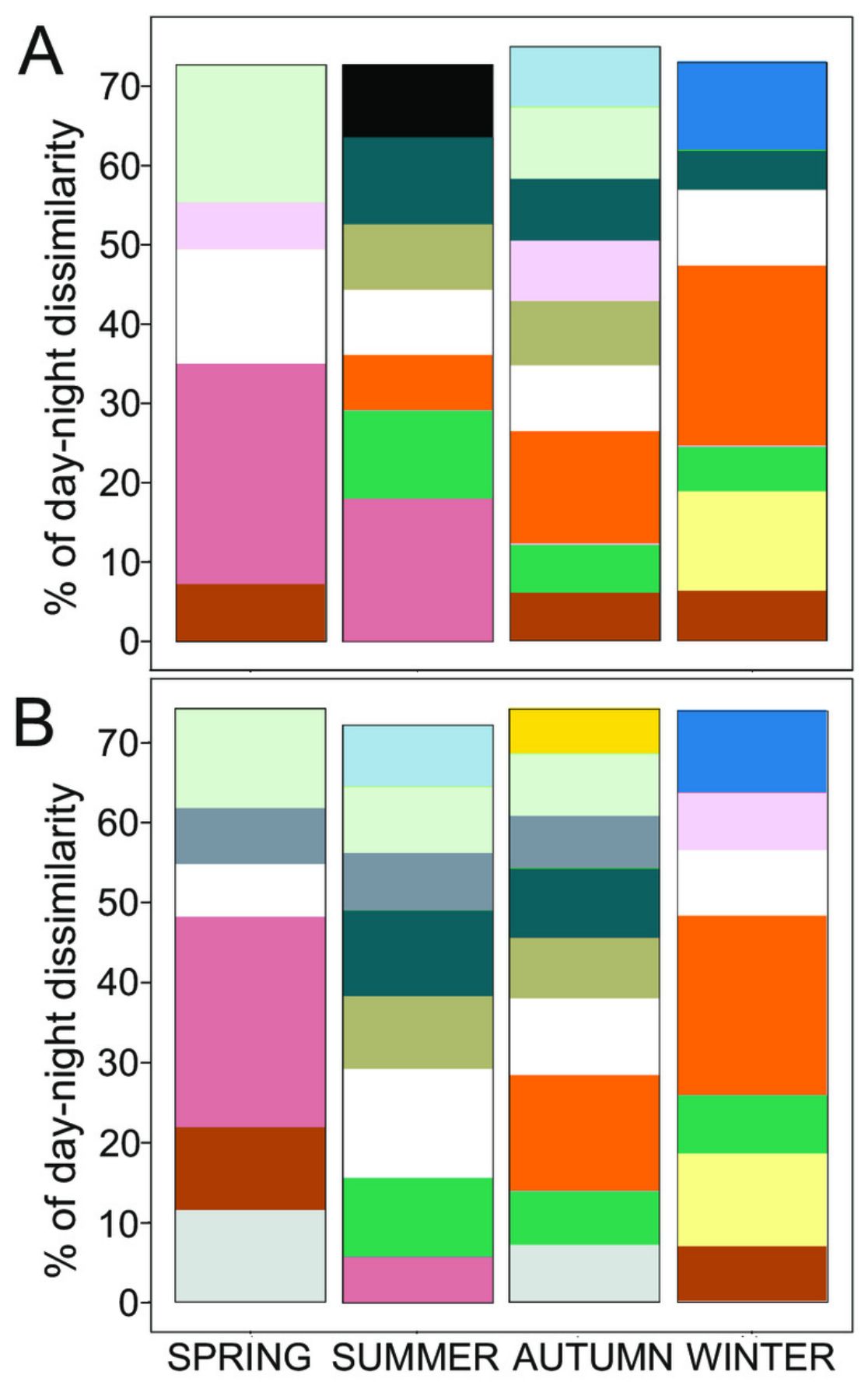

\begin{tabular}{|ll|}
\hline Aetideidae & Copepoda (nauplii) \\
Appendicularia & Euchaetidae \\
Calanidae & Euphausiacea \\
Calanoida $(<1.5 \mathrm{~mm})$ & Metridinidae \\
Centropagidae & Mysida \\
Chaetognatha & Oncaeidae \\
Clausocalanidae & Ostracoda \\
Cnidaria & Rhincalanidae \\
\hline
\end{tabular}


Figure 5

Zooplankton vertical distribution.

Seasonal, diel and vertical distribution of (A) abundance, (B) biovolume and (C) biomass of the zooplankton community during day and night. 


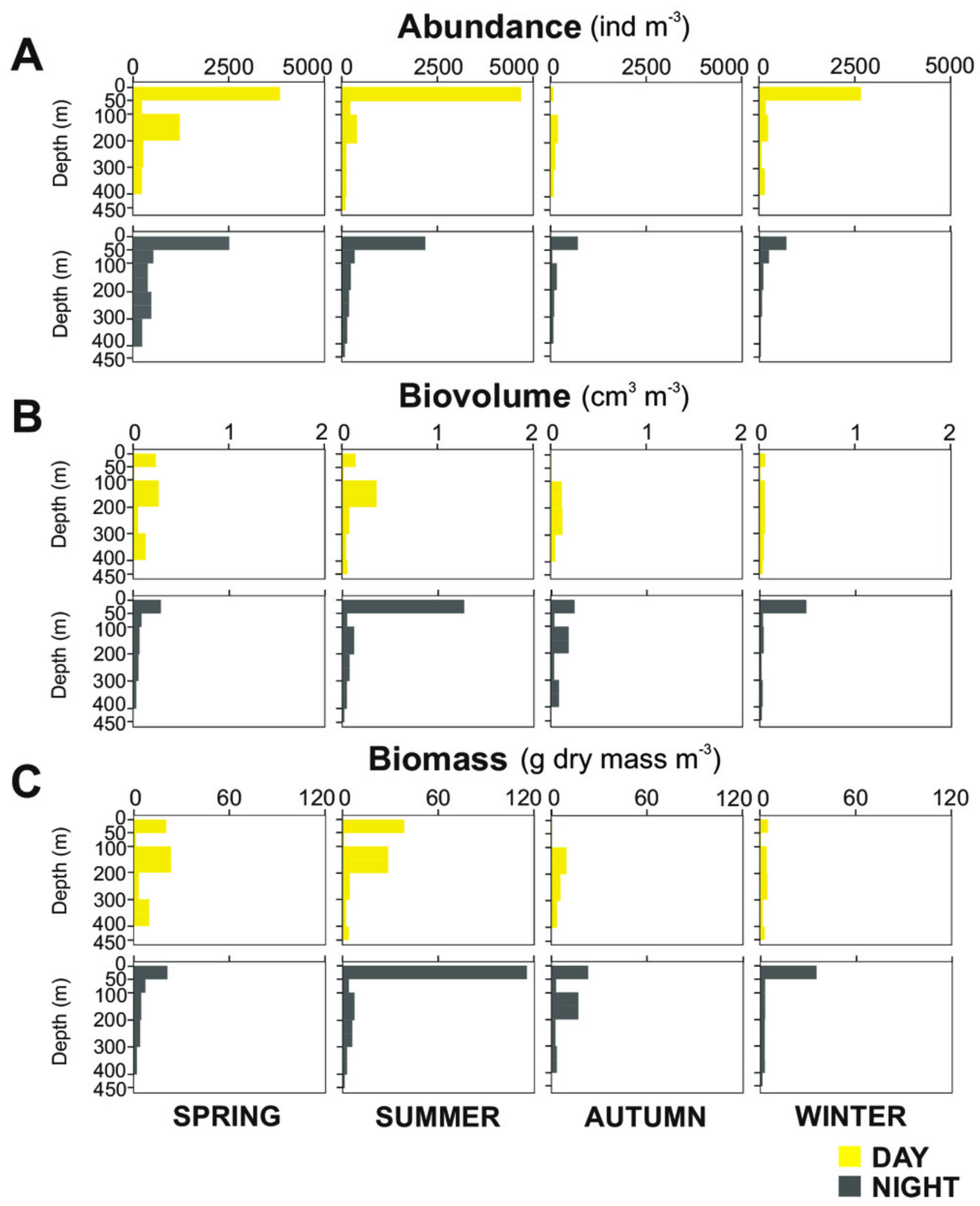


Figure 6

Group dominance of the mesozooplankton taxa.

Relative (A) abundance and (B) biovolume of major zooplankton groups. Taxa comprising less than $3 \%$ of the total zooplankton community ( 27 taxa) were pooled together as "other".
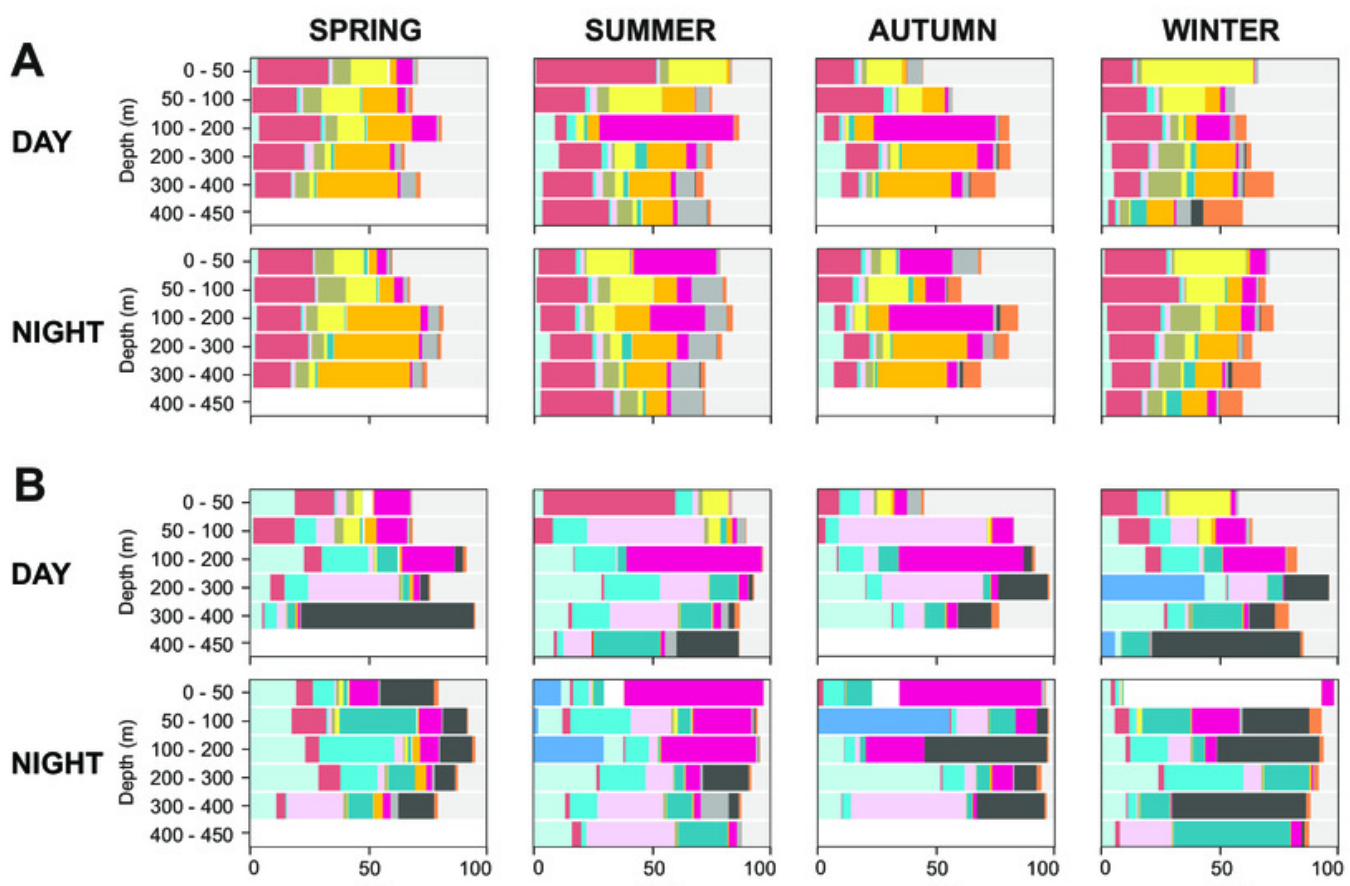

\begin{tabular}{|c|}
\hline Amphipoda \\
\hline Calanidae \\
\hline Calanoida $(<1.5 \mathrm{~mm})$ \\
\hline Chaetognatha \\
\hline Cnidaria \\
\hline Copepoda (nauplii) \\
\hline Cyclopoida \\
\hline Euchaetidae \\
\hline Euphausiacea \\
\hline Harpacticoida \\
\hline Metridinidae \\
\hline Mollusca \\
\hline Mysida \\
\hline Ostracoda \\
\hline other $(<3 \%)$ \\
\hline
\end{tabular}

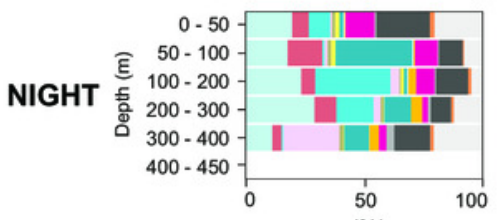

(\%)

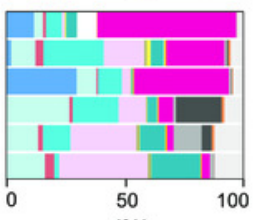

(\%)

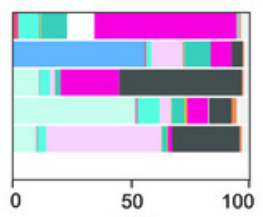

(\%)

(\%) 


\section{Figure 7}

Seasonal, diel and vertical distribution of the most important taxa.

Vertical, diel and seasonal distribution of the most important taxa representing the percent of abundance and biovolume (\%) in relation to their total abundance and biovolume. In (A) is presented the total sum of biovolume and abundance in all samples. Vertical distributions of (B) Metridinidae, (C) Calanidae, (D) Harpacticoida, (E) Cnidaria, (F) Mysida, (G) Chaetognatha, (H) Cyclopoida and (I) Euchaetidae. The group "calanoids $(<1.5 \mathrm{~mm})$ ", although more than $5 \%$ in both, biovolume and abundance, is not represented here as it is composed of a mix of taxa with different functions. 
A
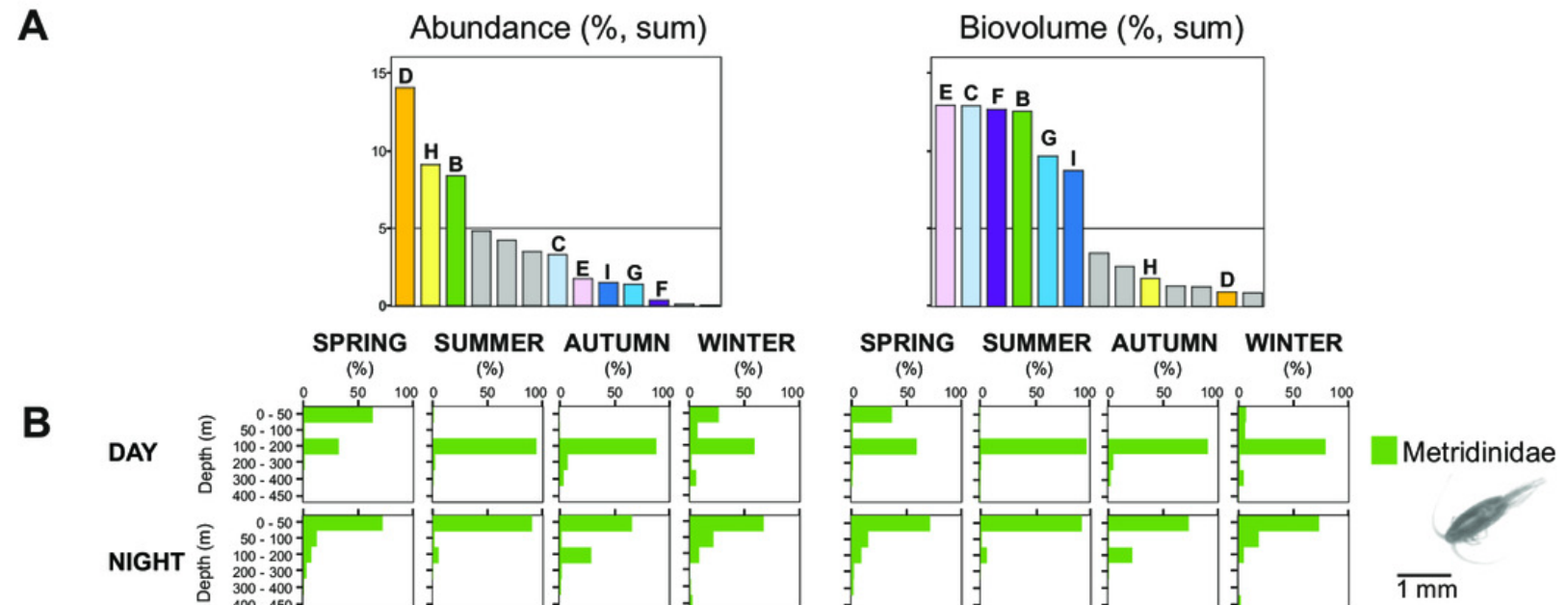

C

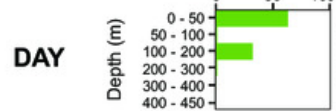

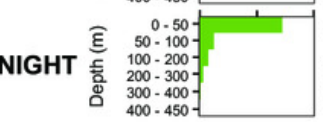

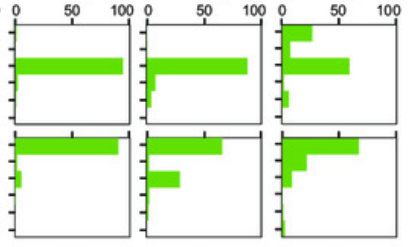

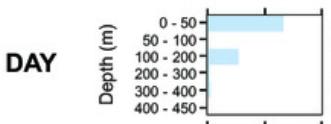
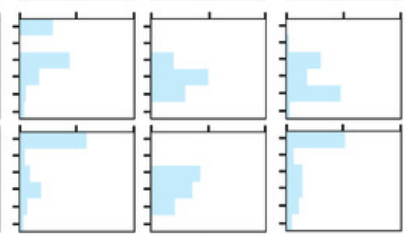

D
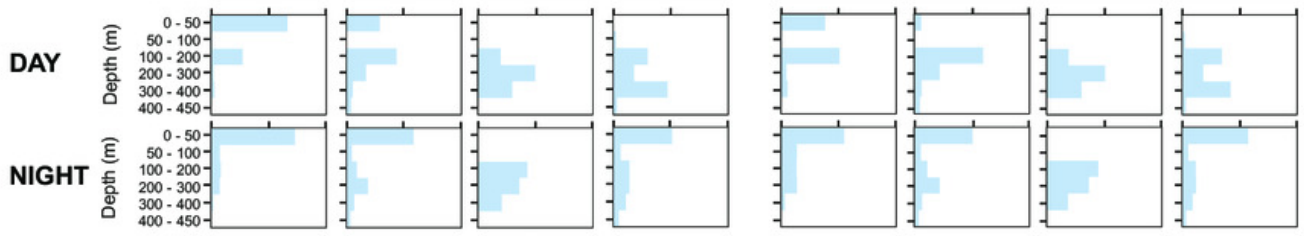

Calanidae

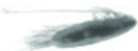

$\overline{1 \mathrm{~mm}}$

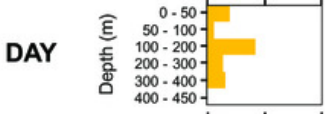

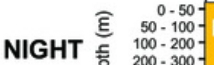

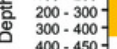

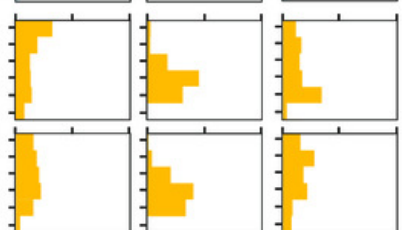

E
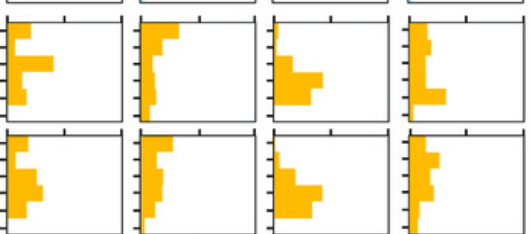

Harpacticoida
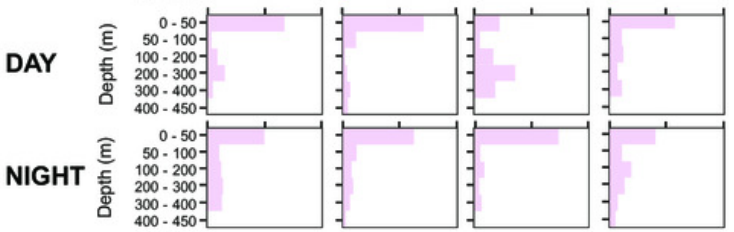

$\mathbf{F}$
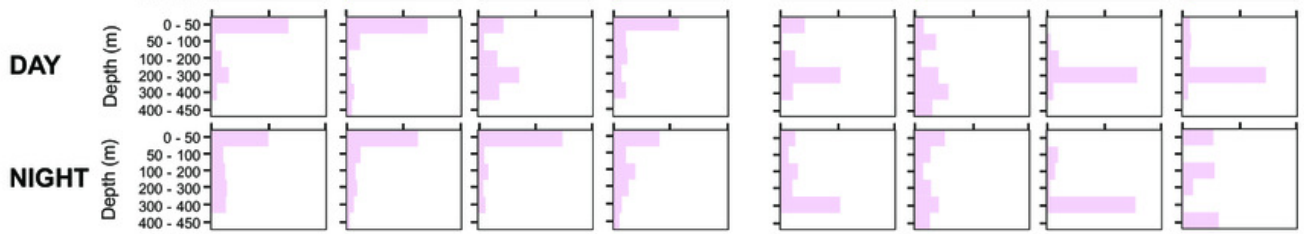

$1 \mathrm{~mm}$
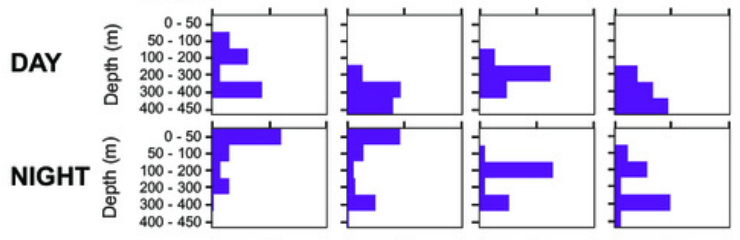

G
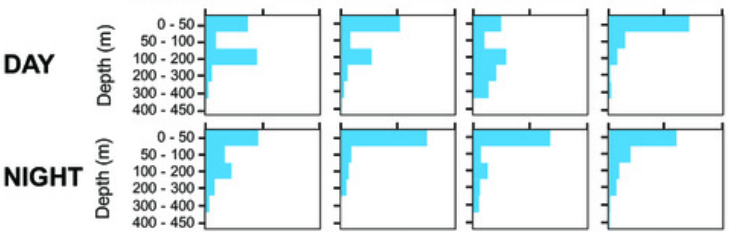

H
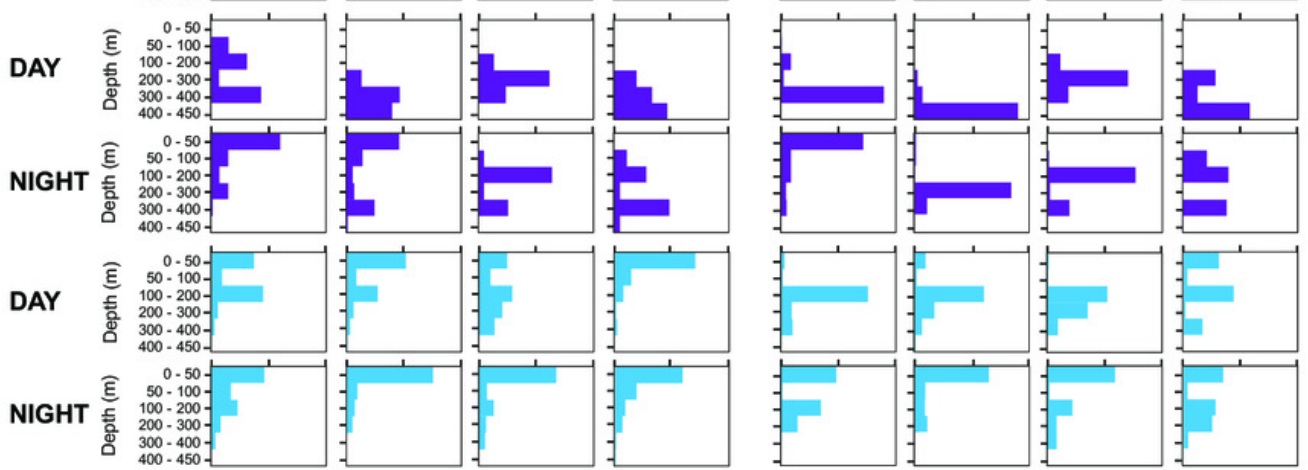

$\overline{1 \mathrm{~mm}}$

Cnidaria
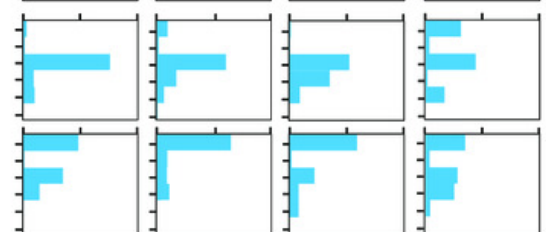

Mysida
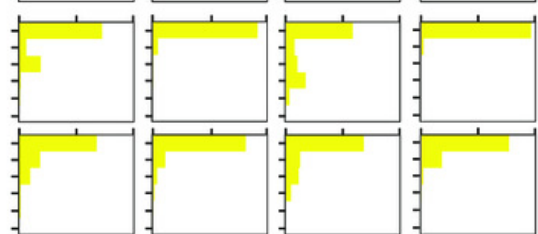

$1 \overline{\mathrm{m}}$

Chaetognatha

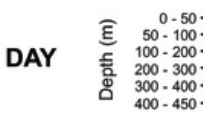

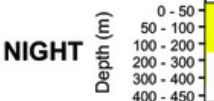
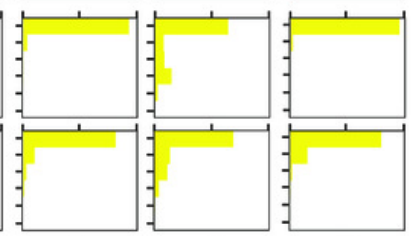

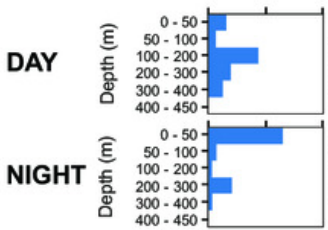
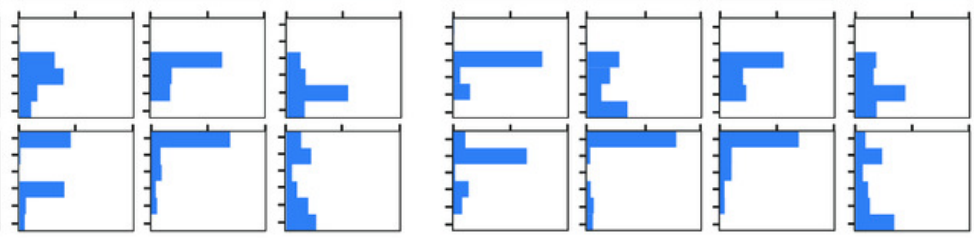

Cyclopoida

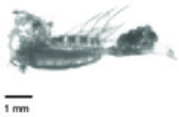


Figure 8

Size frequency distribution of Metridinidae and Calanidae (Copepoda).

Seasonal, diel and vertical size-frequency distribution of (A) Metridinidae and (B) Calanidae.

(\#) provides the number of individuals measured. 


\section{A Metridinidae}

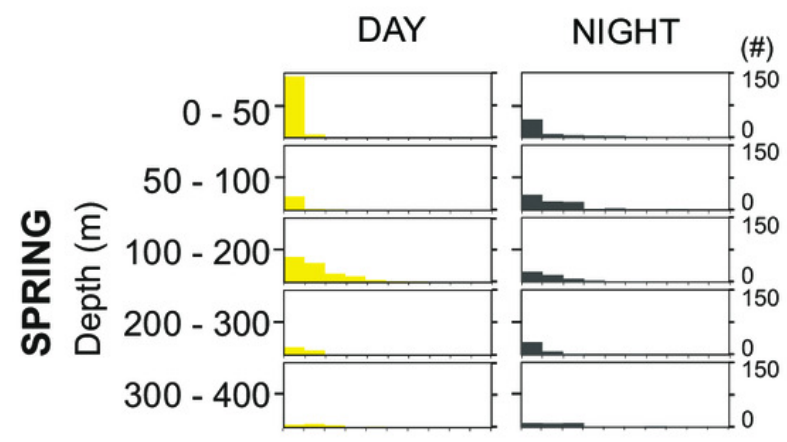

$400-450$
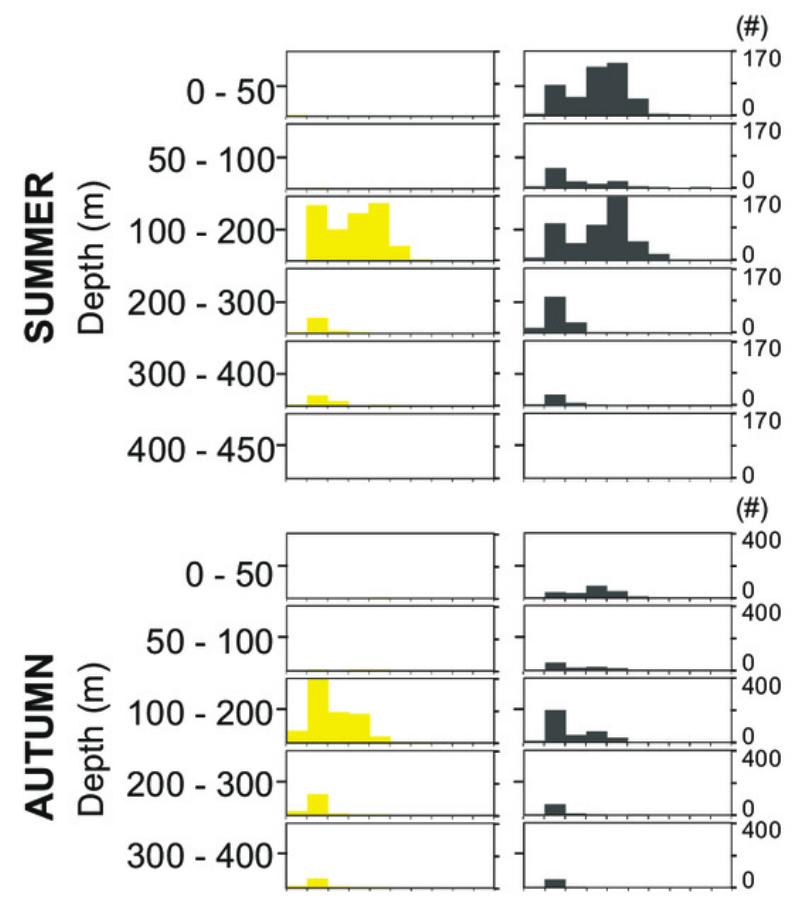

$400-450$

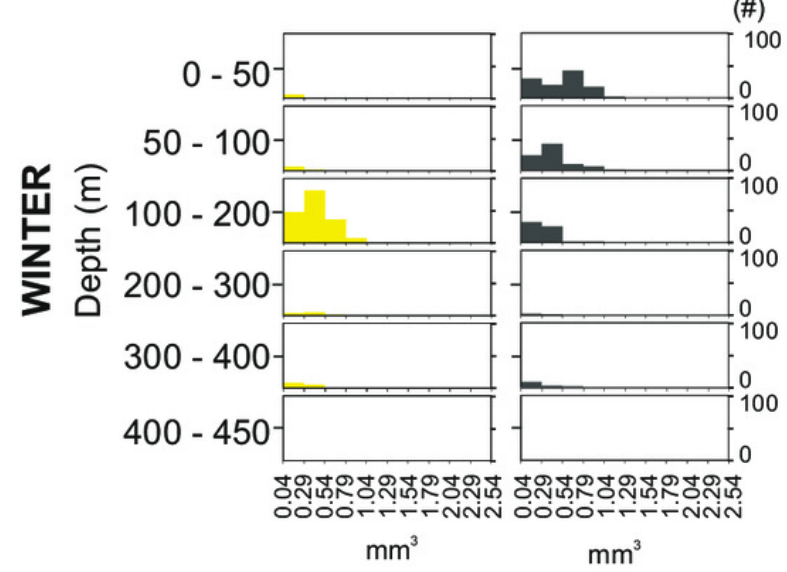

B Calanidae
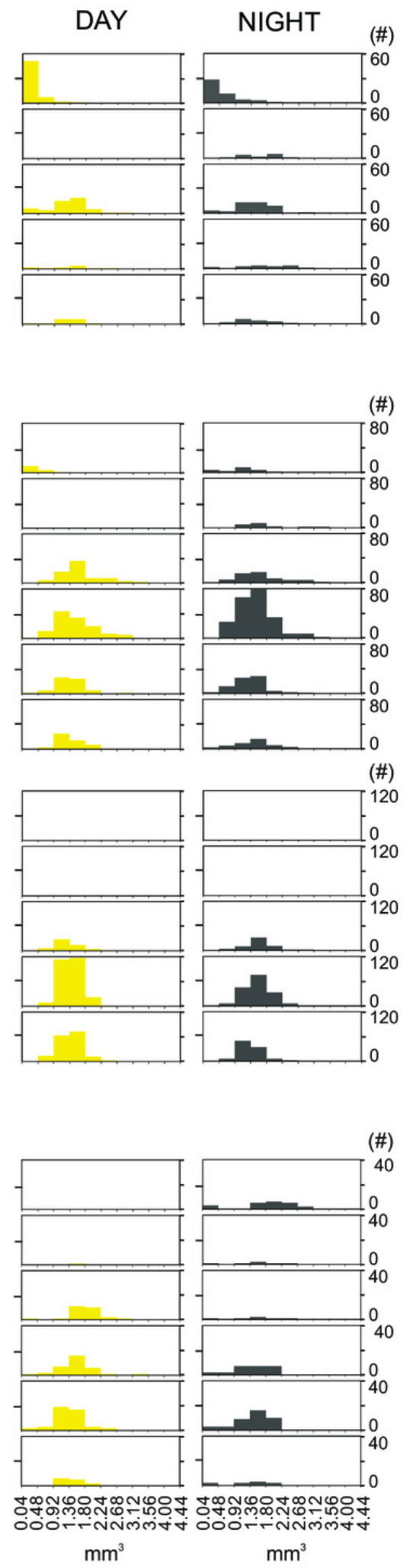
Figure 9

Non-carnivore copepods versus carnivore zooplankton.

Presented as percentages of (A) total abundance and (B) total biovolume.

A
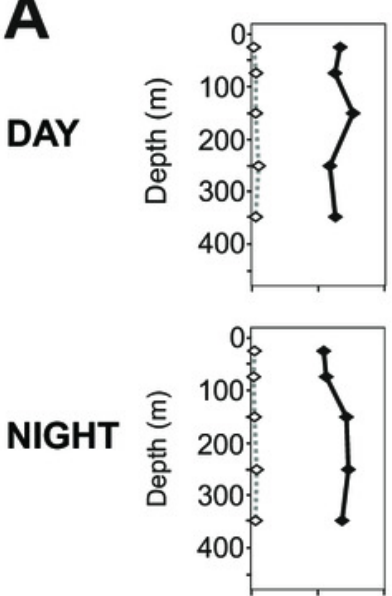

B
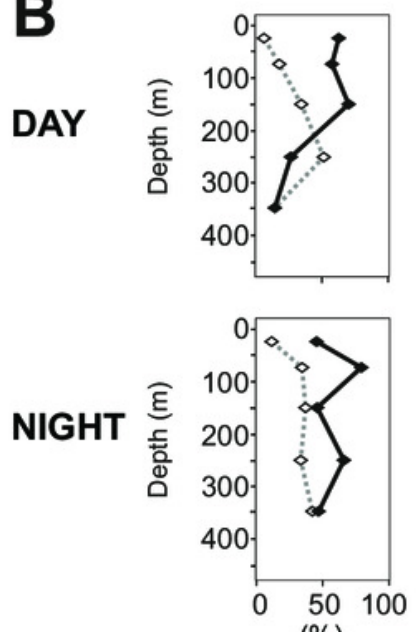

(\%)
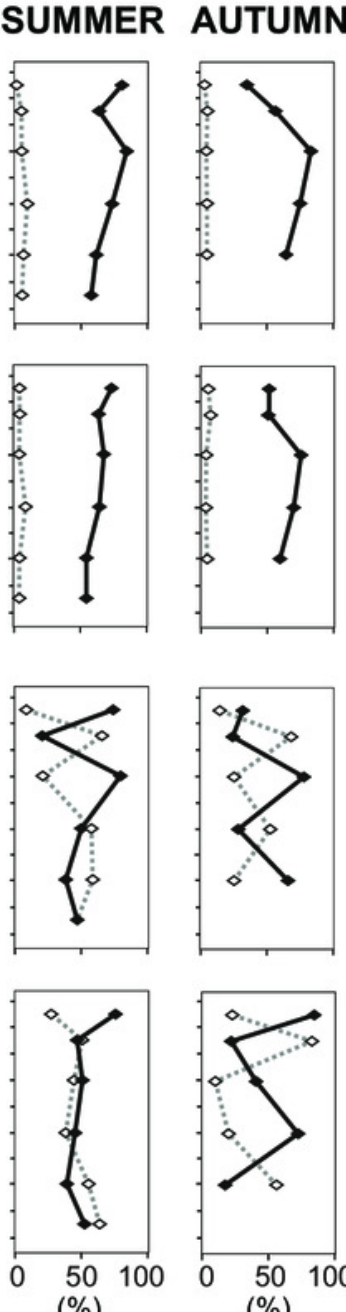

(\%)
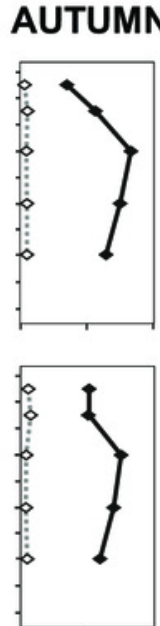
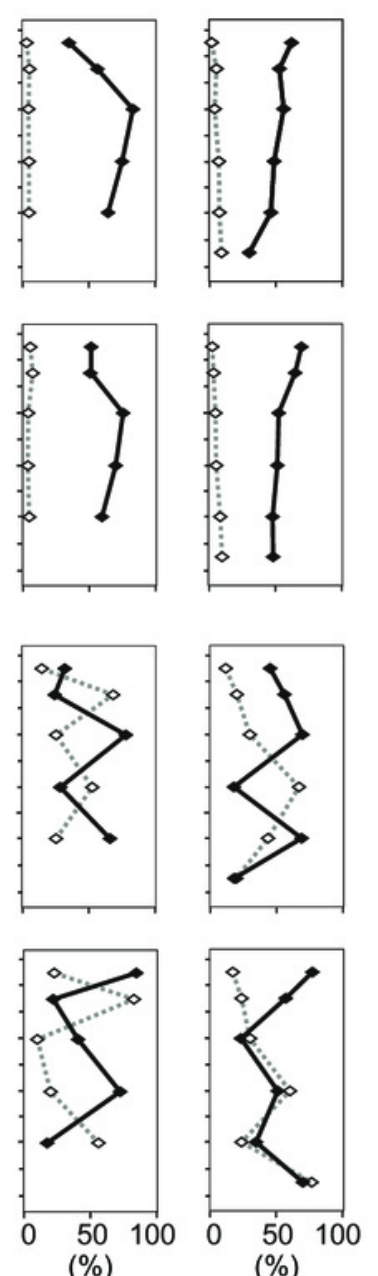

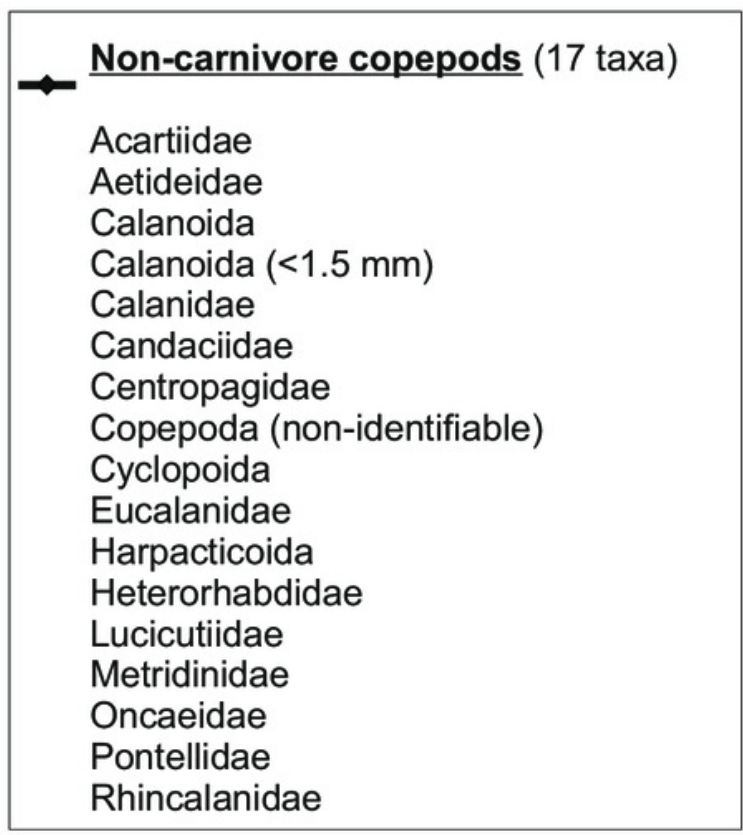

$\diamond$ Carnivore zooplankton (5 taxa):

Actinopterygii

Amphipoda

Chaetognatha

Cnidaria

Euchaetidae 